\title{
Modern Aspects of Immunotherapy with Checkpoint Inhibitors in Melanoma
}

\author{
Vera Petrova 1,2, Ihor Arkhypov 1,2, Rebekka Weber ${ }^{1,2}$, Christopher Groth ${ }^{1,2}$, Peter Altevogt ${ }^{1,2}$, \\ Jochen Utikal ${ }^{1,2}$ and Viktor Umansky ${ }^{1,2, *}$ \\ 1 Clinical Cooperation Unit Dermato-Oncology, German Cancer Research Center (DKFZ), 69120 Heidelberg, \\ Germany; Vera.Petrova@medma.uni-heidelberg.de (V.P.); Ihor.Arkhypov@medma.uni-heidelberg.de (I.A.); \\ rebekka.weber@dkfz.de (R.W.); c.groth@dkfz.de (C.G.); p.altevogt@dkfz.de (P.A.); j.utikal@dkfz.de (J.U.) \\ 2 Department of Dermatology, Venereology and Allergology, University Medical Center Mannheim, \\ University of Heidelberg, 68167 Mannheim, Germany \\ * Correspondence: v.umansky@dkfz.de; Tel.: +49-621-3833773
}

Received: 10 March 2020; Accepted: 27 March 2020; Published: 30 March 2020

check for updates

\begin{abstract}
Although melanoma is one of the most immunogenic tumors, it has an ability to evade anti-tumor immune responses by exploiting tolerance mechanisms, including negative immune checkpoint molecules. The most extensively studied checkpoints represent cytotoxic T lymphocyte-associated protein-4 (CTLA-4) and programmed cell death protein 1 (PD-1). Immune checkpoint inhibitors (ICI), which were broadly applied for melanoma treatment in the past decade, can unleash anti-tumor immune responses and result in melanoma regression. Patients responding to the ICI treatment showed long-lasting remission or disease control status. However, a large group of patients failed to respond to this therapy, indicating the development of resistance mechanisms. Among them are intrinsic tumor properties, the dysfunction of effector cells, and the generation of immunosuppressive tumor microenvironment (TME). This review discusses achievements of ICI treatment in melanoma, reasons for its failure, and promising approaches for overcoming the resistance. These methods include combinations of different ICI with each other, strategies for neutralizing the immunosuppressive TME and combining ICI with other anti-cancer therapies such as radiation, oncolytic viral, or targeted therapy. New therapeutic approaches targeting other immune checkpoint molecules are also discussed.
\end{abstract}

Keywords: melanoma; immunotherapy; immune checkpoint inhibitors; immunosuppression; tumor microenvironment

\section{Introduction}

The concept of cancer immunosurveillance is based on the fact that tumor cells can be recognized and eliminated by immune system [1,2]. Immunogenicity of malignant melanoma is based on a high ultraviolet-driven mutational burden [3]. This leads to the overexpression of tumor specific antigens enabling the formation of the antigen specific immune response [4,5]. However, development of aggressive metastatic melanoma shows that tumors are edited by the immune system, and selected resistant variants could escape the immune control $[6,7]$. Therefore, several immune-based therapeutic approaches such as vaccination [8], adoptive transfers [9] and immune checkpoint-blockade [10] were applied, aiming at reinvigorating anti-tumor immune response and improving survival of advanced-stage melanoma patients [11].

The most studied negative immune checkpoint molecules and broadly accepted targets for immunotherapy are cytotoxic $T$ lymphocyte-associated protein-4 (CTLA-4) and programmed cell death protein 1 (PD-1). CTLA-4 is upregulated on the T cell surface early during activation in lymph nodes, 
binds to CD80/CD86 reducing co-stimulation through CD28 and functions as a negative downstream loop for T cell receptor (TCR) signaling [12]. PD-1 interaction with its ligands PD-L1 and PD-L2 inhibits effector T cell functions in peripheral tissues [13]. Playing a pivotal role in the maintenance of self-tolerance under physiological conditions, these checkpoint molecules could be exploited by tumors to evade the immune responses. Hence, inhibiting such interactions could reactivate anti-tumor immune reactions [14]. Moreover, the combination of anti-CTLA-4 and anti-PD-1 antibodies was shown to work synergistically by expanding activated effector CD8 T cells $[15,16]$. Another approach was shown to implicate the combination of PD-L1-CD80 heterodimerization and the suppression of the CTLA-4/CD80 axis [17]. Currently used antibodies to target CTLA-4 are ipilimumab and tremelimumab, to target PD-1 are nivolumab, pembrolizumab, cemiplimab and to target PD-L1 are atezolizumab and avelumab $[14,18,19]$.

This review will focus on current achievements in the therapy with immune checkpoint inhibitors (ICI) in melanoma and will discuss the strategies to improve of treatment efficacy by combining ICI with other therapies.

\section{Therapeutic Effects of Immune Checkpoint Inhibitors}

Latest clinical guidelines on melanoma management consider immune checkpoint blockade (anti-PD-1 alone or in combination with anti-CTLA4) as a first-line treatment option for unresectable stage III and IV melanoma patients [20,21]. In cases of resectable melanoma, anti-PD1 agents are prescribed as well in an adjuvant setting [22]. This treatment is currently investigating in a neoadjuvant setting [23].

Since the responses of tumors to immunotherapy and chemotherapy are different, immune-related response criteria and immune-response evaluation criteria in solid tumors were developed [24,25]. Such criteria improve the evaluation of additional response patterns during immunotherapy such as pseudoprogression. Currently achieved response to ICI treatment of melanoma patients reached $52 \%$ for pembrolizumab and 58\% for combination of nivolumab and ipilimumab [26-28]. The 5-year survival rate was reported to be $41 \%$ and $52 \%$ in these two trials, respectively. These therapeutic achievements were associated with a high toxicity up to 59\% of grade 3 and 4 adverse events in patients treated with the combination of nivolumab and ipilimumab [27]. Another trial studied a ipilimumab combination with pembrolizumab, which does not yet belong to the approved settings. The objective response was achieved by $61 \%$ of patients, 1 -year overall survival (OS) was $89 \%$, and 1-year progression-free survival was $69 \%$. Grade 3 and 4 adverse events occurred in $27 \%$ of patients [29]. These data represent a favorable effect of such combinations with increased response values and less high-grade adverse effects.

However, many patients remained resistant to ICI therapy since tumor cells could develop resistance to anti-tumor immune reactions or induce a profound immunosuppression in the tumor microenvironment [30].

\section{Tumor Cells Evade Immune Responses}

A characteristic gene profile was described for melanoma cells resistant to ICI. It includes the repression of genes, which control antigen presentation and interferon (IFN)- $\gamma$ signaling as well as the induction of genes regulating epithelial-mesenchymal transition, remodeling of extracellular matrix, cell adhesion and angiogenesis [31-34]. Interestingly, down-regulation of major histocompatibility complex (MHC) class I protein expression was found to be associated with the resistance to anti-CTLA-4, but not to anti-PD-1 therapy [35]. In the same work, MHC class II expression in $>1 \%$ melanoma cells was shown to predict response to anti-PD-1, but not to anti-CTLA-4 therapy. This suggests that tumor cells disrupt antigen presentation limiting the efficient anti-tumor response. In fact, anti-PD-1 blockade before antigen priming of $\mathrm{T}$ cells leads to accumulation of the dysfunctional PD- $1^{+} \mathrm{CD} 38^{\text {hi }} \mathrm{CD} 8^{+}$cells abolishing the effects of the therapy [36]. Moreover, tumor cells can prevent the formation of anti-tumor 
$\mathrm{T}$ cell memory in the draining lymph node by secreting PD-L1-bearing extracellular vesicles (EV), contributing to the resistance to anti-PD-1 antibodies [37].

\section{Immunosuppressive Tumor Microenvironment as an Important Factor of ICI Treatment Failure}

A deeper investigation of the immunosuppressive networks within the TME could help to understand the limitations of ICI treatment and to develop strategies for increasing treatment efficiency. Immunosuppression in the TME is mediated by various cells and soluble factors described below.

\subsection{Myeloid-Derived Suppressor Cells (MDSC)}

MDSC represent a heterogeneous population of immunosuppressive myeloid cells, generating under chronic inflammation conditions and cancer and accumulating in the TME [38]. In humans, three MDSC subsets have been described: $\mathrm{CD} 11 \mathrm{~b}^{+} \mathrm{CD} 14^{+} \mathrm{HLA}-\mathrm{DR}{ }^{\text {low/- }} \mathrm{CD} 15^{-} \mathrm{Lin}^{-}$monocytic (M-MDSC), CD14-CD11b+CD15 ${ }^{+} \mathrm{HLA}-\mathrm{DR}{ }^{\text {low } /-} \mathrm{Lin}^{-}$polymorphonuclear (PMN) MDSC, and HLA-DR low/- CD33 ${ }^{\text {dim }} \mathrm{CD} 6 \mathrm{~b}^{-} \mathrm{Lin}^{-}$early-stage MDSC (e-MDSC) [39]. MDSC could inhibit anti-tumor functions of $\mathrm{T}$ and natural killer (NK) cells via different mechanisms. They can express PD-L1 and FasL and cause T cell anergy and apoptosis [40]. The induction of hypoxia-inducible factor- $1 \alpha(\mathrm{HIF}-1 \alpha)$ through transforming growth factor- $\beta$ (TGF- $\beta$ ) and hypoxic conditions leads to the upregulation of the ectoenzymes CD39 and CD73, producing immunosuppressive adenosine in the extracellular space [40,41]. Reactive oxygen species (ROS) and nitric oxide (NO) produced by MDSC induce T cell apoptosis and the down-regulation of TCR $\zeta$-chain expression [41,42]. Furthermore, MDSC can stimulate regulatory $\mathrm{T}$ cell (Treg) activity [43].

Previous studies demonstrated that high frequency of MDSC in the peripheral blood of advanced melanoma patients correlated with disease progression, decreased overall and progression free survival as well as decreased efficacy of immunotherapy, making them a promising therapeutic target [44-47]. There are different ways to suppress the immunosuppressive activity of MDSC [48]. Normalization of myelopoiesis and depletion of immunosuppressive MDSC could be achieved by using all-trans retinoic acid (ATRA) [49,50], tyrosine-kinase inhibitors [51,52] or some chemotherapeutic agents such as gemcitabine or paclitaxel $[53,54]$.

Another approach of targeting MDSC represents an inhibition of their immunosuppressive activity. Based on the preclinical data showing that phosphodiesterase (PDE)-5 inhibitor sildenafil could suppress MDSC activity, enhance T cell functionality and prolong survival of melanoma-bearing mice $[55,56]$, another PDE-5 inhibitor tadalafil was applied in advanced, therapy-resistant melanoma patients. Therapy was well-tolerated, and $25 \%$ of treated patients showed stable disease (SD) with the progression free survival (PFS) of 4.6 months [57]. Moreover, patients with SD showed increased infiltration of activated $\mathrm{CD} 8^{+} \mathrm{T}$ cells in the metastasis as compared to non-responding patients.

Since the main immunosuppressive effect of MDSC is observed in the TME, the inhibitors of their recruitment to the tumor were tested. Small molecule inhibitor of C-X-C motif chemokine receptor (CXCR) 1 and CXCR2 SX-682 was demonstrated to suppress PMN-MDSC migration and activity, and enhance the efficiency of ICI therapy in mouse oral carcinoma and Lewis lung carcinoma model [58]. In human, SX-682 has been recently applied to advanced melanoma patients alone or in combination with pembrolizumab (Table 1). This table contains ongoing clinical trials, including the combination of ICI with targeting of various immunosuppressive cells (MDSC, CAF, TAM, Treg) and tumor cells as well as with targeting of processes and molecules such as hypoxia, microbiome, neoantigens, and epigenetic mutations. In addition, we included trials combining classical ICI with targeted therapies and new immune checkpoint molecules as well. 
Table 1. Ongoing combinatorial clinical trials.

\begin{tabular}{|c|c|c|c|c|}
\hline Targets & Trial Number & Intervention & Disease & Trial Phase \\
\hline \multirow{4}{*}{ MDSC } & NCT03200847 & $\begin{array}{l}\text { ATRA (Vesanoid) }+ \\
\text { pembrolizumab }\end{array}$ & Advanced melanoma & I, II \\
\hline & NCT02403778 & ATRA + ipilimumab & Advanced melanoma & II \\
\hline & NCT03161431 & $\begin{array}{l}\text { SX-682 alone or in combination } \\
\text { with pembrolizumab }\end{array}$ & Melanoma (III, IV) & I \\
\hline & NCT02259231 & $\begin{array}{l}\text { RTA } 408 \text { (Omaveloxolone) + } \\
\text { nivolumab or ipilimumab }\end{array}$ & $\begin{array}{c}\text { Unrespectable or metastatic } \\
\text { melanoma }\end{array}$ & $\mathrm{Ib}, \mathrm{II}$ \\
\hline CAF & NCT03875079 & RO6874281 + pembrolizumab & Metastatic melanoma & $\mathrm{Ib}$ \\
\hline TAM & NCT01363206 & $\begin{array}{c}\text { GM-CSF (Leukine, } \\
\text { Sargramostim) + ipilimumab }\end{array}$ & $\begin{array}{l}\text { Unresectable metastatic } \\
\text { melanoma }\end{array}$ & II \\
\hline \multirow{7}{*}{ Treg } & NCT02203604 & Aldesleukin (IL-2) + ipilimumab & Metastatic melanoma (IIIA-IV) & II \\
\hline & NCT02983045 & $\begin{array}{c}\text { NKTR-214 (PEGylated IL-2) + } \\
\text { nivolumab with or without } \\
\text { ipilimumab }\end{array}$ & $\begin{array}{l}\text { Advanced malignancies, } \\
\text { including melanoma }\end{array}$ & I, II \\
\hline & NCT03548467 & $\begin{array}{l}\text { NKTR-214 after prior anti-PD-1 } \\
\text { therapy }\end{array}$ & $\begin{array}{l}\text { Advanced malignancies, } \\
\text { including melanoma }\end{array}$ & I, II \\
\hline & NCT03635983 & $\begin{array}{l}\text { NKTR-214 + nivolumab or } \\
\text { nivolumab alone }\end{array}$ & $\begin{array}{l}\text { Untreated, inoperable or } \\
\text { metastatic melanoma }\end{array}$ & III \\
\hline & NCT03138889 & NKTR-214 + pembrolizumab & $\begin{array}{l}\text { Advanced malignancies, } \\
\text { including melanoma }\end{array}$ & I, II \\
\hline & NCT03435640 & $\begin{array}{l}\text { Intratumoral NKTR-262 + } \\
\text { systemic NKTR-214 with or } \\
\text { without nivolumab }\end{array}$ & $\begin{array}{c}\text { Melanoma and other cancer } \\
\text { types }\end{array}$ & I, II \\
\hline & NCT03635983 & $\begin{array}{l}\text { NKTR-214 + nivolumab or } \\
\text { nivolumab alone }\end{array}$ & $\begin{array}{l}\text { Untreated, inoperable or } \\
\text { metastatic melanoma }\end{array}$ & III \\
\hline \multirow{4}{*}{ Microbiome } & NCT03341143 & $\begin{array}{l}\text { Fecal microbiota transplant } \\
(\text { FMT })+\text { pembrolizumab }\end{array}$ & $\begin{array}{c}\text { Advanced melanoma patients, } \\
\text { non-responders }\end{array}$ & II \\
\hline & NCT03817125 & $\begin{array}{l}\text { Vancomycin or placebo } \\
\text { pretreatment }+ \text { nivolumab }+ \\
\text { SER-401 or placebo }\end{array}$ & $\begin{array}{l}\text { Unresectable or metastatic } \\
\text { melanoma }\end{array}$ & $\mathrm{Ib}$ \\
\hline & NCT03772899 & $\begin{array}{c}\text { FMT for a healthy donor a week } \\
\text { before approved melanoma } \\
\text { treatment } \\
\text { (pembrolizumab/nivolumab) }\end{array}$ & Advanced melanoma & I \\
\hline & NCT03643289 & $\begin{array}{c}\text { Comparison of gut microbiome } \\
\text { before and during anti-PD-1 } \\
\text { therapy (till week 9) }\end{array}$ & Advanced melanoma stage IV & Observational \\
\hline \multirow{2}{*}{ Hypoxia } & NCT03311308 & $\begin{array}{l}\text { Metformin + pembrolizumab or } \\
\text { pembrolizumab alone }\end{array}$ & $\begin{array}{l}\text { Advanced, unresectable } \\
\text { melanoma stage III or IV }\end{array}$ & I \\
\hline & NCT03171064 & $\begin{array}{l}\text { Exercise + nivolumab or } \\
\text { pembrolizumab }\end{array}$ & Metastatic melanoma & II \\
\hline \multirow{6}{*}{ Tumor cells } & NCT02799901 & $\begin{array}{l}\text { Hypofractionated radiation } \\
\text { therapy (RT) ( } 27 \text { Gy over } 3 \\
\text { fractions) + nivolumab }\end{array}$ & Advanced melanoma & II \\
\hline & NCT03693014 & $\begin{array}{l}\text { Hypofractionated RT + } \\
\text { Ipilimumab, Nivolumab or } \\
\text { Pembrolizumab, continued } \\
\text { according to the standard } \\
\text { schedule }\end{array}$ & $\begin{array}{c}\text { Metastatic cancer, including } \\
\text { melanoma }\end{array}$ & II \\
\hline & NCT02406183 & Ipilimumab + RT & Metastatic melanoma & I \\
\hline & NCT04042506 & Nivolumab + RT & Metastatic melanoma & II \\
\hline & NCT04017897 & $\begin{array}{l}\text { Anti-PD1 (pembrolizumab or } \\
\text { nivolumab) + RT }\end{array}$ & $\begin{array}{l}\text { Unresectable, naive metastatic } \\
\text { melanoma } \\
\text { (IIIB to IVM1c) }\end{array}$ & II \\
\hline & NCT01449279 & Ipilimumab + RT & Metastatic melanoma & II \\
\hline
\end{tabular}


Table 1. Cont

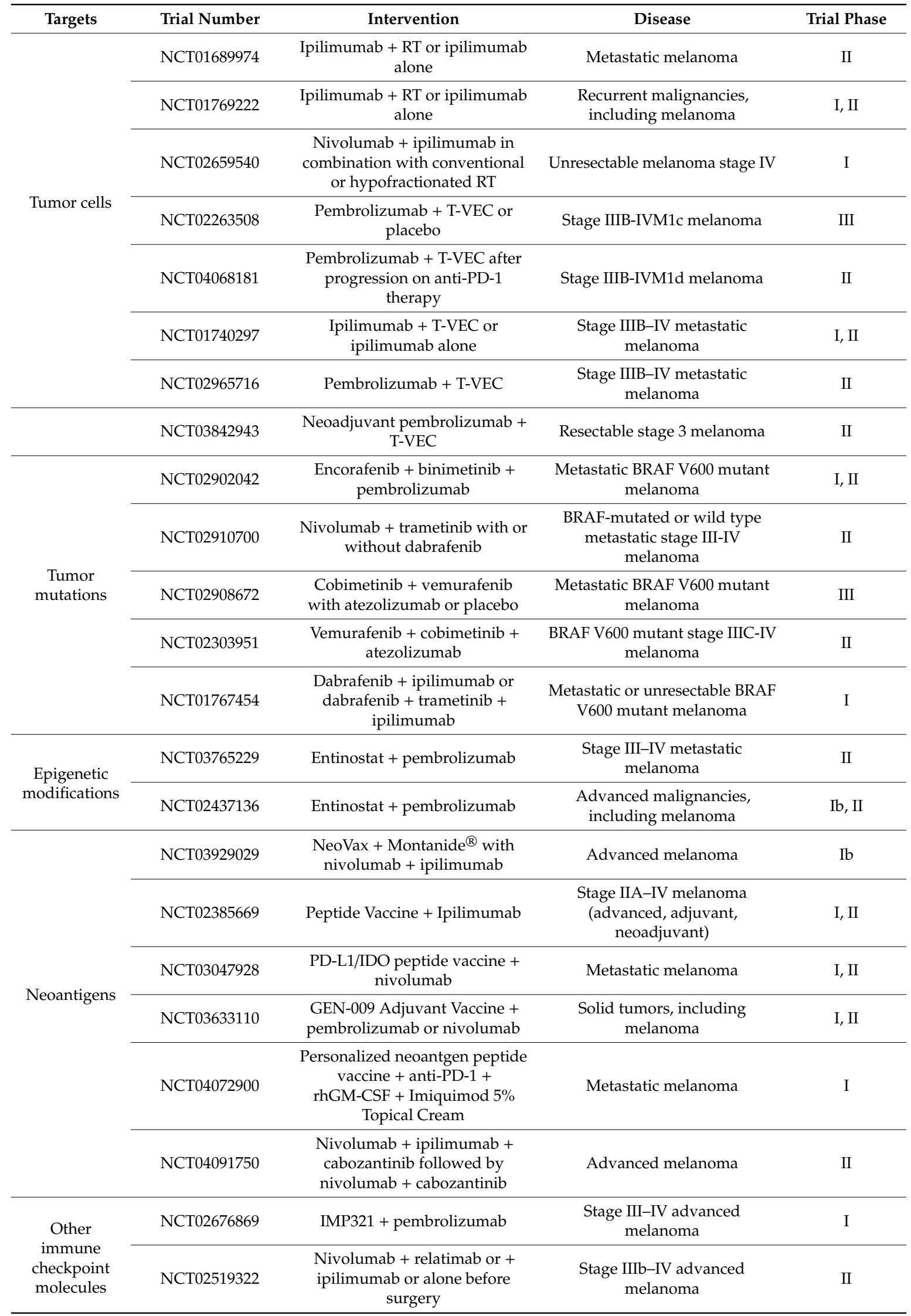


Table 1. Cont.

\begin{tabular}{|c|c|c|c|c|}
\hline Targets & Trial Number & Intervention & Disease & Trial Phase \\
\hline \multirow{8}{*}{$\begin{array}{l}\text { Other } \\
\text { immune } \\
\text { checkpoint } \\
\text { molecules }\end{array}$} & NCT03743766 & $\begin{array}{c}\text { Relatimab + nivolumab or each } \\
\text { drug alone followed by } \\
\text { relatimab + nivolumab in all } \\
\text { subjects }\end{array}$ & $\begin{array}{l}\text { Unresectable or metastatic } \\
\text { melanoma }\end{array}$ & II \\
\hline & NCT03470922 & $\begin{array}{l}\text { Relatimab + nivolumab or } \\
\text { nivolumab alone }\end{array}$ & $\begin{array}{c}\text { Unresectable or metastatic } \\
\text { melanoma }\end{array}$ & II, III \\
\hline & NCT03652077 & $\begin{array}{l}\text { INCAGN02390 antibody against } \\
\text { TIM-3 alone }\end{array}$ & $\begin{array}{l}\text { Advanced malignancies, } \\
\text { including melanoma }\end{array}$ & I \\
\hline & NCT04139902 & $\begin{array}{c}\text { Neoadjuvant therapy with PD-1 } \\
\text { inhibitor dostarlimab (TSR-042) } \\
\text { or dostarlimab (TSR-042) + } \\
\text { TSR-022 (TIM-3 inhibitor) }\end{array}$ & $\begin{array}{l}\text { Stage IIIB-IV } \\
\text { advanced melanoma }\end{array}$ & II \\
\hline & NCT03708328 & $\begin{array}{l}\text { RO7121661, bispecific anti-PD-1 } \\
\text { and anti-TIM-3 antibody }\end{array}$ & $\begin{array}{l}\text { Advanced malignancies, } \\
\text { including melanoma }\end{array}$ & I \\
\hline & NCT02817633 & $\begin{array}{l}\text { TSR-022 (anti-TIM-3) alone or + } \\
\text { TSR-042 (anti-PD-1) or triple } \\
\text { combination of TSR-022 } \\
\text { (anti-TIM-3), TSR-042 } \\
\text { (anti-PD-1) and TSR-033 } \\
\text { (anti-LAG3) }\end{array}$ & $\begin{array}{l}\text { Advanced malignancies, } \\
\text { including melanoma }\end{array}$ & I \\
\hline & NCT03628677 & $\begin{array}{l}\text { AB154 (anti-TIGIT) alone or }+ \\
\text { AB122 (anti-PD-1) }\end{array}$ & $\begin{array}{l}\text { Advanced malignancies, } \\
\text { including melanoma }\end{array}$ & I \\
\hline & NCT03119428 & $\begin{array}{l}\text { OMP-313M32 (anti-TIGIT) alone } \\
\text { or + nivolumab }\end{array}$ & $\begin{array}{l}\text { Advanced malignancies, } \\
\text { including melanoma }\end{array}$ & I \\
\hline
\end{tabular}

\subsection{Neutrophils}

Exposed by high amounts of TGF- $\beta$, granulocyte-colony stimulating factor (G-CSF) and IFN- $\beta$, tumor associated neutrophils (TAN) lose their anti-tumor functions and start to support tumor progression [59]. TAN have been described to enhance tumor angiogenesis and promote metastasis [60]. High neutrophil to lymphocyte ratio $(\geq 4)$ at the baseline is considered as a powerful prognostic factor associated with reduced PFS and OS in melanoma patients treated with immune checkpoint inhibitors [61,62].

\subsection{Cancer-Associated Fibroblasts (CAF)}

$\mathrm{CAF}$ are a major component of the tumor stroma [63]. They produce different cytokines such as TGF- $\beta$, fibroblast growth factor 2 (FGF-2) and vascular endothelial growth factor (VEGF), which lead to the tumor progression [64]. Moreover, an accumulation of CAF was described to correlate with low efficiency of anti-PD-1 therapy [65]. CAF secret fibroblast activation protein (FAP), which suppresses $\mathrm{T}$ cells function and recruitment $[66,67]$. In addition, FAP was reported to be a negative prognostic marker in the absence of immunotherapy but a positive indicative biomarker in ICI treated melanoma patients with a positive impact on PFS and OS [65]. In the murine melanoma model it was shown that stromal fibroblast matrix metalloproteinase-9 mediated surface PD-L1 cleavage, thus leading to the anti-PD-1 therapy resistance [68]. There is an ongoing trial (NCT03875079) to investigate the activity of the FAP-targeting agent RO6874281 in combination with pembrolizumab.

\subsection{Tumor-Associated Macrophages (TAM)}

TAM are known to produce interleukin (IL)- $1 \beta$, cyclooxygenase-2, angiotensin, IFN- $\gamma$ promoting tumorigenesis [69]. These cells can recruit regulatory $\mathrm{T}$ cells (Treg) and inhibit effector $\mathrm{T}$ cells by secreting IL-10 and expressing PD-L1 [70]. CD68 ${ }^{+}$TAM in tumor cell nests were described to be associated with a negative prognosis and recurrence in cutaneous melanoma [70]. Furthermore, the ratio of $\mathrm{CD} 8^{+} \mathrm{T}$ cells to $\mathrm{CD} 68^{+}$macrophages was shown to predict a disease specific survival in 
melanoma [71]. CD163 ${ }^{+}$macrophages were reported to accumulate in the TME of melanoma patients resistant to ICI therapy and to play a role in the maintenance of the immunosuppression. The depletion of $\mathrm{CD}_{163^{+}}$macrophages led to the invasion of activated $\mathrm{T}$ cells and inflammatory monocytes into the tumor, resulting in tumor regression [72,73].

\subsection{Regulatory T Cells}

Treg represent another important part of TME. It has been shown that the amount of forkhead box protein $\mathrm{P} 3$ positive $\left(\mathrm{FOXP3}^{+}\right)$Treg is upregulated in the peripheral blood of melanoma patients [74]. Furthermore, the frequency of circulating $\mathrm{FOXP}^{+}$Treg is associated with a poor prognosis in melanoma [75]. Tumor infiltrating Treg have been described to be a predominant cluster of the cells with high CTLA-4 expression [76]. It was found that the therapy with common anti-CTLA-4 antibodies (ipilimumab) did not deplete Treg in the tumor [77], however, Fc-engineered anti-CTLA-4 antibodies can specifically deplete $\mathrm{FOXP}^{+}$Treg and promote $\mathrm{CD}^{+} \mathrm{T}$ cell expansion, suggesting their higher clinical efficiency than the widely used non-Fc-engineered ipilimumab [76]. In another study, it was reported that the presence of $\mathrm{Fc} \gamma$ receptor-expressing macrophages within the TME is critical for the depletion of tumor-infiltrating Treg [78].

The application of NKTR-214, an engineered cytokine with biased IL-2 receptor binding, was demonstrated to selectively stimulate $\mathrm{CD}^{+} \mathrm{T}$ cells and to deplete Treg in patients with advanced or metastatic solid tumors [79].

\section{Role of Microbiome in the ICI Therapy of Melanoma}

It has recently been clearly demonstrated that the microbiome could influence the ICI therapy in melanoma patients [80]. Although oral microbiome showed no effect on the response to cancer immunotherapy, an enrichment of Clostridiales, Ruminococcaceae, and Faecalibacterium in the gut was associated with response, while an enrichment of Bacteroidales was observed in non-responders and associated with increased risk of relapse [80]. The same study demonstrated that a favorable gut microbiome composition at the baseline was associated with increased $\mathrm{CD} 8^{+} \mathrm{T}$ cell infiltration and anti-tumor immune responses. Furthermore, the fecal transplantation from melanoma patients responding to ICI to germ-free mice led to a better response to anti-PD-1 therapy as compared to mice, receiving gut transplants from non-responding patients [80]. Another study demonstrated that the presence of Bifidobacterium longum, Collinsella aerofaciens, and Enterococcus faecium was associated with a better prognosis in melanoma patients [81]. Moreover, the anti-cancer immunity was described to be affected by the alteration in the metabolism of specific bacterial species but not by their presence [82]. There are several ongoing clinical trials dealing with the gut microbiota transplantation in melanoma patients (Table 1).

\section{Predicting the Response to the ICI Therapy}

Since the response rates to ICI treatment are still restricted [26-29,83], the identification of response-biomarkers before or shortly after the therapy initiation is one of the biggest challenges in the immuno-oncology. Current approaches to predict response to ICI in melanoma are based on the radiology, tumor biopsy and liquid biopsy [84,85].

Radiological imaging (body computer tomography (CT) scan, head magnetic resonance imaging (MRI)) is used to assess the response to ICI treatment in melanoma patients and is routinely performed three months after the start of treatment. Prediction of response in the earlier time points is possible by using ${ }^{18}$ F-FDG PET/CT, where response criteria were developed using the scans made at 21 to 28 days after the start of treatment [86]. This approach was also shown to be beneficial in long-term response prediction and guidance of ICI withdrawal [87-89].

As a part of PD-1/PD-L1 axis, amount of PD-L1 expression on tumor cells was thought to be a distinct predictive marker for therapy response. Although PD-L1 overexpressing tumors showed an association with the higher response to ICI, durable responses could be also observed in PD-L1 negative 
tumors $[90,91]$. Therefore, complementary approaches are needed to improve the prognostic value of tumor PD-L1, including a dynamic monitoring of PD-L1 expression or PD-L1 RNA sequencing [92,93].

Further interest attracts the measurement of PD-L1 (soluble and expressed in extracellular vesicles, EV) in liquid biopsies. Soluble PD-L1 is a splice variant without a transmembrane domain capable to directly inhibit $\mathrm{T}$ cell proliferation and IFN- $\gamma$ production [94]. Elevated basal levels of soluble PD-L1 in the plasma of melanoma patients was associated with progressive disease [95]. Furthermore, the measurement of PD-L1 in EV could help to predict the response to ICI, demonstrating an advantage of the detection in EV over tumor biopsies [96]. Melanoma patients responding to pembrolizumab could be distinguished from non-responders by increased levels of EV PD-L1 at 3 to 6 weeks after the start of therapy [97]. In another study, it was shown that exosomal PD-L1 mRNA levels decreased during nivolumab or pembrolizumab treatment of melanoma patients with complete or partial response, while in patients with progressive disease EV PD-L1 expression was increased [98].

Besides PD-L1, soluble CD163 and macrophage-related chemokines (e.g., C-X-C motif chemokine ligand (CXCL) 5, 10) were reported to predict efficacy of ICI [85]. Decreased serum levels of IL-8 at 2 to 4 weeks after the start of ICI treatment were associated with the response in patients even with the initial pseudoprogression [99]. Induction of CXCR3 ligands in murine melanoma model was described to increase the response to the therapy with anti-PD1 antibodies, and elevated CXCR3 levels were observed in plasma of responding melanoma patients [100].

Another predictive marker could be the amount of tumor-infiltrating $\mathrm{T}$ cells. It has been shown that $\mathrm{T}$ cells dominated among other immune cells, accumulated in human melanoma metastatic tissue [101]. Strong pre-existing T cell infiltration, IFN- $\gamma$-related gene expression signatures in the tumor and high serum level of IFN- $\gamma$ were reported to be associated with a good clinical prognosis and to predict the response to anti-PD-1 therapy in melanoma patients [101-105]. It was reported that $98 \%$ of PD-L1 ${ }^{+}$tumors were associated with high TIL numbers and the PD-L1 ${ }^{+}$melanoma cells were localized adjacent to TILs [106].

\section{Increasing Effectiveness of ICI Therapy}

In order to enhance the beneficial therapeutic effect of ICI, this treatment was combined with other anti-tumor therapies. Since radiation therapy (RT) is used in melanoma patients and can induce antigen release from tumors, its combination with immunotherapy was applied, leading to the $\mathrm{T}$ cell activation and improvement of OS without increasing the number of adverse events $[107,108]$. In a retrospective study with 208 melanoma patients with brain metastasis treated with anti-PD-1 antibodies and RT, the survival rates at 6 and 12 months after the start of treatment were $77 \%$ and $70 \%$, respectively [109]. There are numerous ongoing trials investigating the combination of immuno- and radiation therapy in metastatic melanoma patients (Table 1).

Another promising approach to increase the efficiency of ICI is to combine it with metformin, a drug for type II diabetes. Metformin was shown to induce not only cell cycle arrest in melanoma cells, leading to their autophagy and apoptosis, but also to affect the TME [110]. It is known that metformin activates AMP-activated protein kinase a (AMPKa) in mitochondria, which lead to the downregulation of HIF- $1 \alpha$ expression, resulting in reduced intratumoral hypoxia. Metformin was also reported to promote $\mathrm{T}$ cell activity in the combination with ICI, leading to B16 melanoma rejection in mice [111]. In a clinical trial, it was shown that the combination of ICI and metformin increased objective response rate (ORR), disease control rate (DCR), PFS and OS in comparison with the group treated with ICI alone [112]. However, due to a small patient cohort, these changes were not statistically significant.

Interestingly, the reduction of tumor hypoxia could be achieved by a physical exercise as well. In B16F10 mouse melanoma model, voluntary wheel running resulted in the epinephrine-dependent, IL-6-sensitive NK cell activation and increased migration of NK and T cells into the tumor [113]. In addition, a physical activity prior to tumor cells inoculation led to a strong reduction of primary tumor growth and numbers of lung metastasis in those mice. Other study demonstrated that the growth of B16F10 melanoma in mice on high-fat diet was accelerated as compared to mice receiving a 
balanced diet [114]. Importantly, this growth increase was significantly reduced by continuous physical exercise that was associated with the lymphocyte proliferation [114]. In melanoma patients, exercises undertaken before diagnosis were not significantly correlated with a reduction in cancer-related or overall mortality [115]. However, in patients with unresectable stage III or IV melanoma undergoing immunotherapy, the reduction of fatigue was shown to be the main positive impact of physical activity [116]. The ongoing combinational trial is represented in the Table 1.

Targeted therapies (BRAF and MEK-inhibitors) are known to be effective in patients with BRAF-V600 mutation and achieve rapid response with a high response rate [117]. The median maintenance of response to this therapy is approximately one year because of the development of acquired resistance [118], while ICI have been described to induce durable response. It was reported that $33 \%$ of melanoma patients achieved complete response when treated with the combination of dabrafenib and trametinib with spartalizumab (anti-PD-L1-antibody); the 1-year OS was 86\%; however, the number of grade $\geq 3$ adverse events was $75 \%$ [119]. In another study, dabrafenib and trametinib were combined with pembrolizumab (triple therapy) or placebo (double therapy) [120]. The median duration of response in tripled therapy group was 18.7 months and 12.5 months in double therapy group. PFS was 16.0 months in triple and 10.3 months in double therapy. In a smaller patient's cohort, an objective response was achieved in $73 \%$ of patients, and $40 \%$ maintained the response at a median follow-up of 27.0 months [121]. $73 \%$ of patients from the same cohort developed grade 3 and 4 adverse events. Another trial, investigating the combination of atezolizumab (anti-PD-L1-anibody), cobimetinib and vemurafenib showed similar results with an objective response rate of $71.8 \%$ and median duration of response of 17.4 months; $39.4 \%$ of patients maintained response for 29.9 months of follow-up [122]. These data suggest that this combination therapy can increase the maintenance of the response, but the high grades of adverse events need to be taken into account. Ongoing trials to the triple combination are shown in Table 1.

ICI could also be combined with the oncolytic virus talimogen laherparepvec (T-VEC) that was approved for melanoma immunotherapy. T-VEC is a genetically modified virus, which replicates in tumor cells causing cancer cell lysis [123]. It has been reported that the intratumoral T-VEC injection in combination with pembrolizumab led to increased $\mathrm{CD} 8^{+} \mathrm{T}$ cells infiltration associated with the ORR rate of $62 \%$ and the CR in $33 \%$ of patients [124].

Combination of all-trans retinoic acid (ATRA) with ipilimumab was reported to decrease frequency of circulating MDSC as well as the expression of PD-L1, IL-10, and indoleamine 2,3-dioxygenase by MDSC, whereas in the ipilimumab monotherapy group the MDSC frequency increased during the treatment [125]. Furthermore, patients receiving combinational treatment tend to have an increased activated $\mathrm{CD} 107 \mathrm{a}^{+} \mathrm{IFN}-\gamma^{+} \mathrm{CD} 8^{+} \mathrm{T}$ cell numbers compared to the patients treated with ipilimumab alone.

Combination of NKTR-214 and Nivolumab was shown to achieve response rates of 53\%, which correlated with high IFN- $\gamma$ levels [126]. Furthermore, the accumulation of IFN- $\gamma$ and CD8 ${ }^{+}$TIL in tumor tissue had been seen in favorable as well as in unfavorable tumor microenvironment. The ongoing trials investigating the combination of NKTR-214 with ICI in metastatic melanoma patients are listed in Table 1.

It was demonstrated that epigenetic modulation induced by the histone deacetylase inhibitor entinostat (MS-275) could enhance the antigen presentation in tumor cells and inhibit immunosuppressive activity of MDSC and Treg [127,128]. After combining entinostat with the anti-PD-1 antibodies, $19 \%$ of non-responding to anti-PD-1 therapy melanoma patients, achieved objective response [129]. These data represent a new approach to overcome resistance using epigenetics. Other ongoing trials using this combination are listed in Table 1.

A new approach of targeting different TME components using nanoparticles has been recently proposed [130]. In melanoma mouse models, nanoparticles were shown to potentiate the efficiency of PD-1 blockade [131-133], to reduce the tumor volume and to prolong mouse survival [134]. 


\section{Other ICI in Malignant Melanoma}

In addition to PD-L1 and CTLA-4, several other immune checkpoint molecules have been investigated during the last decade. Among them are lymphocyte activation gene-3 (LAG-3), T-cell immunoglobulin- and mucin domain- containing molecule 3 (TIM-3) and T cell immunoreceptor with Ig and ITIM domains (TIGIT). All these molecules were reported to be highly expressed on immune cells in the TME, especially on TILs and Treg, which makes them a promising target for cancer immunotherapy [135].

LAG-3 is expressed on activated CD4 ${ }^{+}$and CD8 ${ }^{+} \mathrm{T}$ cells, Treg, B and NK cells as well as DC [136]. It interacts with MHCII molecules on APC or with Galectin-3 and liver sinusoidal endothelial cell lectin (LSECtin) on cancer cells, leading to the inhibition of $\mathrm{CD} 4^{+}$and $\mathrm{CD} 8^{+} \mathrm{T}$ cell proliferation and decreased cytokine secretion [137]. Such inhibition of T cell function was found to be associated with the promotion of tumor growth and tumor escape $[138,139]$. LAG-3 blocking could be achieved by LAG-3-Ig fusion protein or LAG-3 targeting antibody (relatlimab). The treatment of melanoma patients with relatlimab resulted in the ORR of $16 \%$ and DCR of $45 \%$ [140]. Interestingly, only $9 \%$ of patients had grade 3 or 4 adverse events that was comparable to the therapy with nivolumab.

TIM-3 is expressed on $\mathrm{CD}^{+}$and $\mathrm{CD}^{+}$T cells, Treg, B cells, NK cells, DC, mast cells and macrophages. Under physiological conditions, it serves as a negative regulator of Th1 response and Th1 related production of TNF and IFN- $\gamma$; therefore, its blockade could lead to autoimmune disease [141]. Interaction of TIM-3 with Galectin-9 expressed on tumor cells was reported to result in CD8 TIL apoptosis in colon cancer [142]. In melanoma high expression of TIM-3 was associated with CD8 T cell exhaustion [143].

TIGIT was reported to be involved in the inhibition of $\mathrm{CD} 8^{+} \mathrm{T}$ cells and modulation of DC activity, resulting in the upregulation of IL-10 and downregulation of IL-12 production [144,145]. Moreover, TIGIT was demonstrated to play a crucial role in the maturation of naïve T cells to Foxp3 ${ }^{+}$Treg [146]. TIGIT $^{+}$Tregs showed higher immunosuppressive potential than their TIGIT' ${ }^{-}$counterparts [147]. In malignant melanoma, the co-expression of PD-L1, LAG-3, TIM-3 and TIGIT was demonstrated to induce CD8 ${ }^{+}$TILs with most exhausted phenotype $[125,126]$. Double blockage of PD-1 and TIGIT in melanoma led to an increased proliferation and cytokine production of $\mathrm{CD} 8^{+}$TIL and was considered to be a promising approach in immunotherapy [148]. The ongoing clinical trials evaluating the efficiency of LAG-3, TIM-3 and TIGIT blockade are shown in Table 1.

\section{Conclusions}

Despite of melanoma immunogenicity, this tumor develops immune escape mechanisms that stimulate a fast melanoma progression. Such mechanisms include impaired antigen presentation by tumor cells, accumulation of dysfunctional effector $\mathrm{T}$ cells and generation of the immunosuppressive TME represented by MDSC, TAN, CAF, TAM, and Treg. Therefore, numerous approaches were developed to reinvigorate the anti-tumor immune response. Recently approved immunotherapies with ICI (anti-PD-1, anti-PD-L1 and anti-CTLA-4 antibodies) have revolutionized the treatment of melanoma. This treatment significantly increased the survival of melanoma patients and provided a durable control of the disease [26-28]. However, the response rates to ICI are still restricted. Thus, further efforts should be undertaken to maximize the efficacy of ICI treatment. This aim could be achieved by improving the selection of patients who might benefit from the ICI therapy, by applying early radiological findings and by measuring predictive markers from tumor and liquid biopsies. Furthermore, the combination of different ICI (such as ipilimumab and nivolumab), their combination with targeting of the immunosuppressive TME or with other anti-cancer therapies could significantly improve the efficacy of tumor immunotherapy. Furthermore, targeting of other immune checkpoints (such as LAG-3, TIM-3, TIGIT) and its combination with approved ICI are currently under investigation (Table 1). Approved ICI, their targets, and targets for combined treatments are summarized in the Figure 1. 


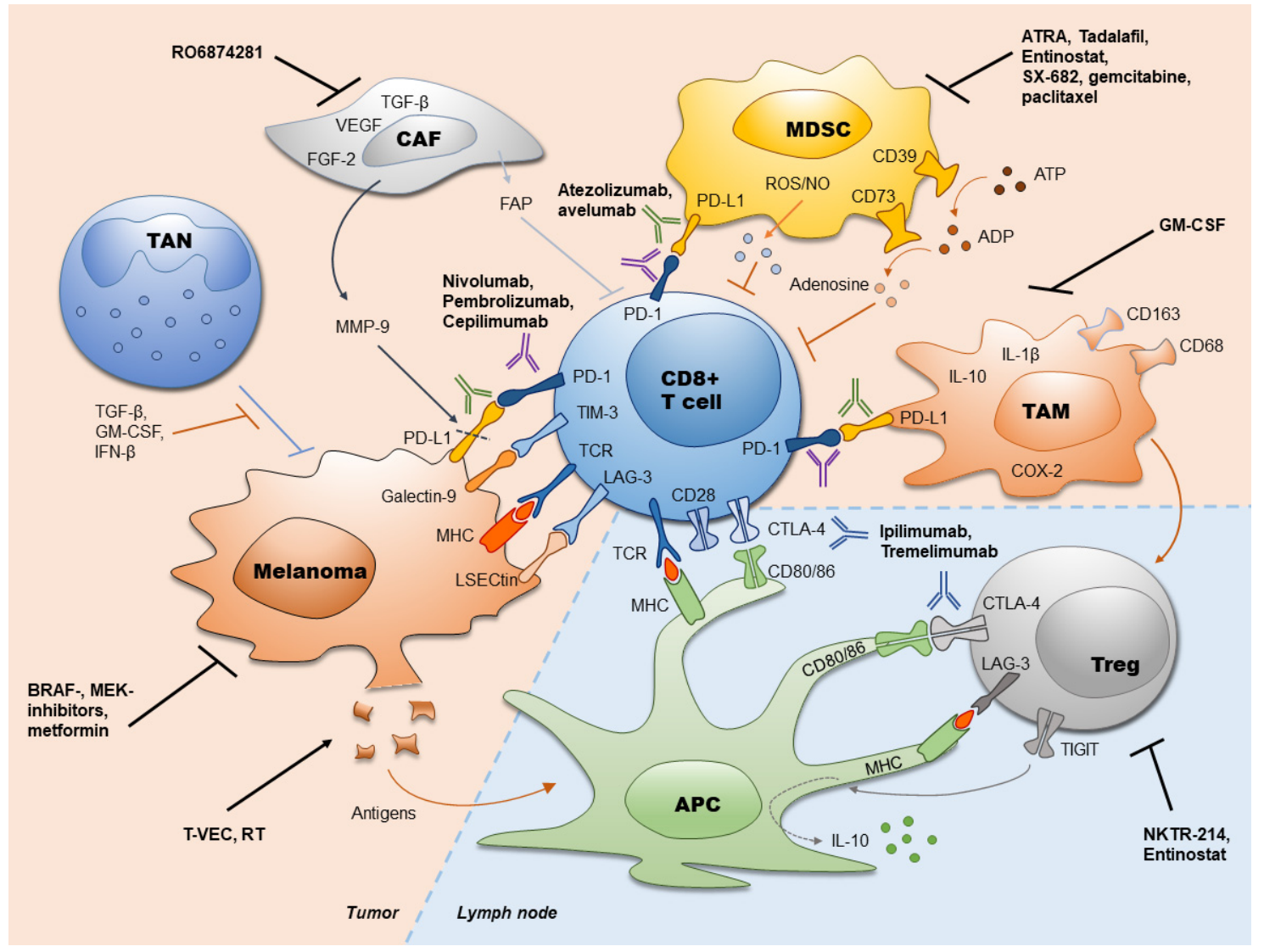

Figure 1. Immune checkpoint inhibitors in melanoma and their combination with other therapies. Currently used antibodies against PD-1 (atezolizumab, avelumab), PD-L1 (nivolumab, pembrolizumab, cepilimumab) and CTLA-4 (ipilimumab, tremelimumab) as well as strategies to increase the efficiency of immune checkpoint inhibitors (ICI) are presented. ADP: adenosine diphosphate; APC: antigen presenting cell; ATP: adenosine triphosphate; ATRA: all-trans retinoic acid; CAF: cancer-associated fibroblasts; COX-2: cyclooxygenase-2; CTLA-4: cytotoxic T lymphocyte-associated protein-4; FAP: fibroblast activation protein; FGF-2: fibroblast growth factor 2; GM-CSF: granulocyte-macrophage colony stimulating factor; IFN- $\beta$ : interferon- $\beta$; IL: interleukin; LAG-3: lymphocyte activation gene-3; LSECtin: liver sinusoidal endothelial cell lectin; MDSC: myeloid-derived suppressor cells; MHC: major histocompatibility complex; MMP-9: matrix metallopeptidase 9; NO: nitric oxide; PD-1: programmed cell death protein 1; PD-L1: programmed cell death ligand 1; ROS: reactive oxygen species; RT: radiation therapy; TAM: tumor-associated macrophages; TAN: tumor associated neutrophils; TCR: T-cell receptor; TGF- $\beta$ : transforming growth factor- $\beta$; TIGIT: T cell immunoreceptor with Ig and ITIM domains; TIM-3: T-cell immunoglobulin- and mucin domain- containing molecule 3; Treg; regulatory T cells; T-VEC: talimogen laherparepvec; VEGF: vascular endothelial growth factor.

Author Contributions: V.P.: writing, review and revision of the manuscript, preparation and revision of the table. I.A.: writing, review and revision of the manuscript, preparation and revision of the figure. R.W., C.G., P.A., J.U.: review and revision of the manuscript. V.U.: writing, review and revision of the manuscript, revision of the figure and table. All authors have read and agreed to the published version of the manuscript.

Funding: This work was supported by grants from the Deutsche Forschungsgemeinschaft (DFG, German Research Foundation, RTG2099 to J.U. and V.U.) and the Cooperation Program in Cancer Research of the Deutsches Krebsforschungszentrum (DKFZ) and Israel's Ministry of Science, Technology and Space (MOST). (CA181 to V.U.).

Conflicts of Interest: The authors declare no potential conflict of interest. 


\section{Abbreviations}

\begin{tabular}{|c|c|}
\hline $\mathrm{ADP}$ & adenosine diphosphate \\
\hline AMPKa & AMP-activated protein kinase a \\
\hline APC & antigen presenting cell \\
\hline ATP & adenosine triphosphate \\
\hline ATRA & all-trans retinoic acid \\
\hline CAF & cancer-associated fibroblasts \\
\hline $\mathrm{COX}-2$ & cyclooxygenase-2 \\
\hline $\mathrm{CT}$ & computer tomography \\
\hline CTLA-4 & cytotoxic T lymphocyte-associated protein- 4 \\
\hline CXCL & C-X-C motif chemokine ligand \\
\hline CXCR & $\mathrm{C}-\mathrm{X}-\mathrm{C}$ motif chemokine receptor \\
\hline DCR & disease control rate \\
\hline EV & extracellular vesicles \\
\hline FAP & fibroblast activation protein \\
\hline FGF-2 & fibroblast growth factor 2 \\
\hline $\mathrm{FOXP3}^{+}$ & forkhead box protein P3 \\
\hline G-CSF & granulocyte-colony stimulating factor \\
\hline GM-CSF & granulocyte-macrophage colony stimulating factor \\
\hline HIF- $1 \alpha$ & hypoxia-inducible factor- $1 \alpha$ \\
\hline ICI & immune checkpoint inhibitors \\
\hline IFN & interferon \\
\hline IL & interleukin \\
\hline LAG-3 & lymphocyte activation gene-3 \\
\hline LSECtin & liver sinusoidal endothelial cell lectin \\
\hline MDSC & myeloid-derived suppressor cells \\
\hline $\mathrm{MHC}$ & major histocompatibility complex \\
\hline MMP-9 & matrix metallopeptidase 9 \\
\hline MRI & magnetic resonance imaging \\
\hline NK & natural killer \\
\hline $\mathrm{NO}$ & nitric oxide \\
\hline ORR & objective response rate \\
\hline OS & overall survival \\
\hline PD-1 & programmed cell death protein 1 \\
\hline PDE & phosphodiesterase \\
\hline PD-L1 & programmed cell death ligand 1 \\
\hline PD-L2 & programmed cell death ligand 2 \\
\hline PFS & progression free survival \\
\hline PMN & polymorphonuclear \\
\hline ROS & reactive oxygen species \\
\hline RT & radiation therapy \\
\hline SD & stable disease \\
\hline TAM & tumor-associated macrophages \\
\hline TAN & Tumor-associated neutrophils \\
\hline TCR & T-cell receptor \\
\hline TGF- $\beta$ & transforming growth factor- $\beta$ \\
\hline TIGIT & T cell immunoreceptor with Ig and ITIM domains \\
\hline TIM-3 & T-cell immunoglobulin- and mucin domain- containing molecule 3 \\
\hline TME & tumor microenvironment \\
\hline Treg & regulatory $\mathrm{T}$ cells \\
\hline T-VEC & talimogen laherparepvec alimogen laherparepvec \\
\hline VEGF & vascular endothelial growth factor \\
\hline
\end{tabular}




\section{References}

1. Dunn, G.P.; Bruce, A.T.; Ikeda, H.; Old, L.J.; Schreiber, R.D. Cancer immunoediting: From immunosurveillance to tumor escape. Nat. Immunol. 2002, 3, 991-998. [CrossRef] [PubMed]

2. Ribatti, D. The concept of immune surveillance against tumors. The first theories. Oncotarget 2017, 8, 7175-7180. [CrossRef] [PubMed]

3. Chalmers, Z.R.; Connelly, C.F.; Fabrizio, D.; Gay, L.; Ali, S.M.; Ennis, R.; Schrock, A.; Campbell, B.; Shlien, A.; Chmielecki, J.; et al. Analysis of 100,000 human cancer genomes reveals the landscape of tumor mutational burden. Genome Med. 2017, 9, 34. [CrossRef] [PubMed]

4. Pitcovski, J.; Shahar, E.; Aizenshtein, E.; Gorodetsky, R. Melanoma antigens and related immunological markers. Crit. Rev. Oncol. Hematol. 2017, 115, 36-49. [CrossRef] [PubMed]

5. Faramarzi, S.; Ghafouri-Fard, S. Melanoma: A prototype of cancer-testis antigen-expressing malignancies. Immunotherapy 2017, 9, 1103-1113. [CrossRef]

6. Schreiber, R.D.; Old, L.J.; Smyth, M.J. Cancer immunoediting: Integrating immunity's roles in cancer suppression and promotion. Science 2011, 331, 1565-1570. [CrossRef]

7. Ko, J.S. The Immunology of Melanoma. Clin. Lab. Med. 2017, 37, 449-471. [CrossRef]

8. Ott, P.A.; Hu, Z.; Keskin, D.B.; Shukla, S.A.; Sun, J.; Bozym, D.J.; Zhang, W.; Luoma, A.; Giobbie-Hurder, A.; Peter, L.; et al. An immunogenic personal neoantigen vaccine for patients with melanoma. Nature 2017, 547, 217-221. [CrossRef]

9. Rohaan, M.W.; Van Den Berg, J.H.; Kvistborg, P.; Haanen, J.B.A.G. Adoptive transfer of tumor-infiltrating lymphocytes in melanoma: A viable treatment option. J. Immunother. Cancer 2018, 6, 102. [CrossRef]

10. Ottaviano, M.; De Placido, S.; Ascierto, P.A. Recent success and limitations of immune checkpoint inhibitors for cancer: A lesson from melanoma. Virchows Arch. 2019, 474, 421-432. [CrossRef]

11. Luke, J.J.; Flaherty, K.T.; Ribas, A.; Long, G.V. Targeted agents and immunotherapies: Optimizing outcomes in melanoma. Nat. Rev. Clin. Oncol. 2017, 14, 463-482. [CrossRef] [PubMed]

12. Sansom, D.M. CD28, CTLA-4 and their ligands: Who does what and to whom? Immunology 2000, 101, $169-177$. [CrossRef] [PubMed]

13. Alsaab, H.O.; Sau, S.; Alzhrani, R.; Tatiparti, K.; Bhise, K.; Kashaw, S.K.; Iyer, A.K. PD-1 and PD-L1 checkpoint signaling inhibition for cancer immunotherapy: Mechanism, combinations, and clinical outcome. Front. Pharmacol. 2017, 8, 561. [CrossRef] [PubMed]

14. Gellrich, F.F.; Schmitz, M.; Beissert, S.; Meier, F. Meier Anti-PD-1 and Novel Combinations in the Treatment of Melanoma-An Update. J. Clin. Med. 2020, 9, 223. [CrossRef]

15. Wei, S.C.; Anang, N.A.A.S.; Sharma, R.; Andrews, M.C.; Reuben, A.; Levine, J.H.; Cogdill, A.P.; Mancuso, J.J.; Wargo, J.A.; Pe'er, D.; et al. Combination anti-CTLA-4 plus anti-PD-1 checkpoint blockade utilizes cellular mechanisms partially distinct from monotherapies. Proc. Natl. Acad. Sci. USA 2019, 116, 22699-22709. [CrossRef]

16. Gide, T.N.; Quek, C.; Menzies, A.M.; Tasker, A.T.; Shang, P.; Holst, J.; Madore, J.; Lim, S.Y.; Velickovic, R.; Wongchenko, M.; et al. Distinct Immune Cell Populations Define Response to Anti-PD-1 Monotherapy and Anti-PD-1/Anti-CTLA-4 Combined Therapy. Cancer Cell 2019, 35, 238-255. [CrossRef]

17. Zhao, Y.; Lee, C.K.; Lin, C.H.; Gassen, R.B.; Xu, X.; Huang, Z.; Xiao, C.; Bonorino, C.; Lu, L.F.; Bui, J.D.; et al. PD-L1:CD80 Cis-Heterodimer Triggers the Co-stimulatory Receptor CD28 While Repressing the Inhibitory PD-1 and CTLA-4 Pathways. Immunity 2019, 51, 1059-1073. [CrossRef]

18. Urwyler, P.; Earnshaw, I.; Bermudez, M.; Perucha, E.; Wu, W.; Ryan, S.; Mcdonald, L.; Karagiannis, S.N.; Taams, L.S.; Powell, N.; et al. Mechanisms of checkpoint inhibition induced adverse events. Clin. Exp. Immunol. 2020. [CrossRef]

19. Wessely, A.; Steeb, T.; Erdmann, M.; Heinzerling, L.; Vera, J.; Schlaak, M.; Berking, C.; Heppt, M.V. Wessely; Steeb; Erdmann; Heinzerling; Vera; Schlaak; Berking; Heppt The Role of Immune Checkpoint Blockade in Uveal Melanoma. Int. J. Mol. Sci. 2020, 21, 879. [CrossRef]

20. Michielin, O.; van Akkooi, A.; Ascierto, P.; Dummer, R.; Keilholz, U. Cutaneous melanoma: ESMO Clinical Practice Guidelines for diagnosis, treatment and follow-up. Ann. Oncol. 2019, 30, 1884-1901. [CrossRef]

21. Coit, D.G.; Thompson, J.A.; Albertini, M.R.; Barker, C.; Carson, W.E.; Contreras, C.; Daniels, G.A.; DiMaio, D.; Fields, R.C.; Fleming, M.D.; et al. Cutaneous Melanoma, Version 2.2019, NCCN Clinical Practice Guidelines in Oncology. J. Natl. Compr. Canc. Netw. 2019, 17, 367-402. [CrossRef] [PubMed] 
22. Weber, J.; Mandala, M.; Del Vecchio, M.; Gogas, H.J.; Arance, A.M.; Cowey, C.L.; Dalle, S.; Schenker, M.; Chiarion-Sileni, V.; Marquez-Rodas, I.; et al. Adjuvant Nivolumab versus Ipilimumab in Resected Stage III or IV Melanoma. N. Engl. J. Med. 2017, 377, 1824-1835. [CrossRef] [PubMed]

23. Amaria, R.N.; Reddy, S.M.; Tawbi, H.A.; Davies, M.A.; Ross, M.I.; Glitza, I.C.; Cormier, J.N.; Lewis, C.; Hwu, W.J.; Hanna, E.; et al. Neoadjuvant immune checkpoint blockade in high-risk resectable melanoma. Nat. Med. 2018, 24, 1649-1654. [CrossRef] [PubMed]

24. Wolchok, J.D.; Hoos, A.; O’Day, S.; Weber, J.S.; Hamid, O.; Lebbé, C.; Maio, M.; Binder, M.; Bohnsack, O.; Nichol, G.; et al. Guidelines for the evaluation of immune therapy activity in solid tumors: Immune-related response criteria. Clin. Cancer Res. 2009, 15, 7412-7420. [CrossRef] [PubMed]

25. Seymour, L.; Bogaerts, J.; Perrone, A.; Ford, R.; Schwartz, L.H.; Mandrekar, S.; Lin, N.U.; Litière, S.; Dancey, J.; Chen, A.; et al. iRECIST: Guidelines for response criteria for use in trials testing immunotherapeutics. Lancet Oncol. 2017, 18, e143-e152. [CrossRef]

26. Hamid, O.; Robert, C.; Daud, A.; Hodi, F.S.; Hwu, W.J.; Kefford, R.; Wolchok, J.D.; Hersey, P.; Joseph, R.; Weber, J.S.; et al. Five-year survival outcomes for patients with advanced melanoma treated with pembrolizumab in KEYNOTE-001. Ann. Oncol. 2019, 30, 582-588. [CrossRef]

27. Hodi, F.S.; Chiarion-Sileni, V.; Gonzalez, R.; Grob, J.J.; Rutkowski, P.; Cowey, C.L.; Lao, C.D.; Schadendorf, D.; Wagstaff, J.; Dummer, R.; et al. Nivolumab plus ipilimumab or nivolumab alone versus ipilimumab alone in advanced melanoma (CheckMate 067): 4-year outcomes of a multicentre, randomised, phase 3 trial. Lancet Oncol. 2018, 19, 1480-1492. [CrossRef]

28. Larkin, J.; Chiarion-Sileni, V.; Gonzalez, R.; Grob, J.J.; Rutkowski, P.; Lao, C.D.; Cowey, C.L.; Schadendorf, D.; Wagstaff, J.; Dummer, R.; et al. Five-year survival with combined nivolumab and ipilimumab in advanced melanoma. N. Engl. J. Med. 2019, 381, 1535-1546. [CrossRef]

29. Long, G.V.; Atkinson, V.; Cebon, J.S.; Jameson, M.B.; Fitzharris, B.M.; McNeil, C.M.; Hill, A.G.; Ribas, A.; Atkins, M.B.; Thompson, J.A.; et al. Standard-dose pembrolizumab in combination with reduced-dose ipilimumab for patients with advanced melanoma (KEYNOTE-029): An open-label, phase $1 \mathrm{~b}$ trial. Lancet. Oncol. 2017, 18, 1202-1210. [CrossRef]

30. Somasundaram, R.; Herlyn, M.; Wagner, S.N. The role of tumor microenvironment in melanoma therapy resistance. Melanoma Manag. 2016, 3, 23-32. [CrossRef]

31. Jerby-Arnon, L.; Shah, P.; Cuoco, M.S.; Rodman, C.; Su, M.J.; Melms, J.C.; Leeson, R.; Kanodia, A.; Mei, S.; Lin, J.R.; et al. A Cancer Cell Program Promotes T Cell Exclusion and Resistance to Checkpoint Blockade. Cell 2018, 175, 984-997. [CrossRef] [PubMed]

32. Riaz, N.; Havel, J.J.; Makarov, V.; Desrichard, A.; Urba, W.J.; Sims, J.S.; Hodi, F.S.; Martín-Algarra, S.; Mandal, R.; Sharfman, W.H.; et al. Tumor and Microenvironment Evolution during Immunotherapy with Nivolumab. Cell 2017, 171, 934-949. [CrossRef] [PubMed]

33. Hugo, W.; Zaretsky, J.M.; Sun, L.; Song, C.; Moreno, B.H.; Hu-Lieskovan, S.; Berent-Maoz, B.; Pang, J.; Chmielowski, B.; Cherry, G.; et al. Genomic and Transcriptomic Features of Response to Anti-PD-1 Therapy in Metastatic Melanoma. Cell 2016, 165, 35-44. [CrossRef] [PubMed]

34. Seliger, B. Basis of PD1/PD-L1 Therapies. J. Clin. Med. 2019, 8, 2168. [CrossRef] [PubMed]

35. Rodig, S.J.; Gusenleitner, D.; Jackson, D.G.; Gjini, E.; Giobbie-Hurder, A.; Jin, C.; Chang, H.; Lovitch, S.B.; Horak, C.; Weber, J.S.; et al. MHC proteins confer differential sensitivity to CTLA-4 and PD-1 blockade in untreated metastatic melanoma. Sci. Transl. Med. 2018, 10, eaar3342. [CrossRef] [PubMed]

36. Verma, V.; Shrimali, R.K.; Ahmad, S.; Dai, W.; Wang, H.; Lu, S.; Nandre, R.; Gaur, P.; Lopez, J.; Sade-Feldman, M.; et al. PD-1 blockade in subprimed CD8 cells induces dysfunctional PD- $1^{+}$CD38 ${ }^{\text {hi }}$ cells and anti-PD-1 resistance. Nat. Immunol. 2019, 20, 1231-1243. [CrossRef] [PubMed]

37. Poggio, M.; Hu, T.; Pai, C.C.; Chu, B.; Belair, C.D.; Chang, A.; Montabana, E.; Lang, U.E.; Fu, Q.; Fong, L.; et al. Suppression of Exosomal PD-L1 Induces Systemic Anti-tumor Immunity and Memory. Cell 2019, 177, 414-427. [CrossRef]

38. Veglia, F.; Perego, M.; Gabrilovich, D. Myeloid-derived suppressor cells coming of age review-article. Nat. Immunol. 2018, 19, 108-119. [CrossRef]

39. Bronte, V.; Brandau, S.; Chen, S.H.; Colombo, M.P.; Frey, A.B.; Greten, T.F.; Mandruzzato, S.; Murray, P.J.; Ochoa, A.; Ostrand-Rosenberg, S.; et al. Recommendations for myeloid-derived suppressor cell nomenclature and characterization standards. Nat. Commun. 2016, 7, 12150. [CrossRef] 
40. Noman, M.Z.; Desantis, G.; Janji, B.; Hasmim, M.; Karray, S.; Dessen, P.; Bronte, V.; Chouaib, S. PD-L1 is a novel direct target of HIF- $1 \alpha$, and its blockade under hypoxia enhanced: MDSC-mediated T cell activation. J. Exp. Med. 2014, 211, 781-790. [CrossRef]

41. Groth, C.; Hu, X.; Weber, R.; Fleming, V.; Altevogt, P.; Utikal, J.; Umansky, V. Immunosuppression mediated by myeloid-derived suppressor cells (MDSCs) during tumour progression. Br. J. Cancer 2019, 120, 16-25. [CrossRef] [PubMed]

42. Raber, P.L.; Thevenot, P.; Sierra, R.; Wyczechowska, D.; Halle, D.; Ramirez, M.E.; Ochoa, A.C.; Fletcher, M.; Velasco, C.; Wilk, A.; et al. Subpopulations of myeloid-derived suppressor cells impair T cell responses through independent nitric oxide-related pathways. Int. J. Cancer 2014, 134, 2853-2864. [CrossRef] [PubMed]

43. Gabrilovich, D.I.; Nagaraj, S. Myeloid-derived suppressor cells as regulators of the immune system. Nat. Rev. Immunol. 2009, 9, 162-174. [CrossRef] [PubMed]

44. Jiang, H.; Gebhardt, C.; Umansky, L.; Beckhove, P.; Schulze, T.J.; Utikal, J.; Umansky, V. Elevated chronic inflammatory factors and myeloid-derived suppressor cells indicate poor prognosis in advanced melanoma patients. Int. J. Cancer 2015, 136, 2352-2360. [CrossRef] [PubMed]

45. Gebhardt, C.; Sevko, A.; Jiang, H.; Lichtenberger, R.; Reith, M.; Tarnanidis, K.; Holland-Letz, T.; Umansky, L.; Beckhove, P.; Sucker, A.; et al. Myeloid cells and related chronic inflammatory factors as novel predictive markers in melanoma treatment with ipilimumab. Clin. Cancer Res. 2015, 21, 5453-5459. [CrossRef]

46. Jordan, K.R.; Amaria, R.N.; Ramirez, O.; Callihan, E.B.; Gao, D.; Borakove, M.; Manthey, E.; Borges, V.F.; McCarter, M.D. Myeloid-derived suppressor cells are associated with disease progression and decreased overall survival in advanced-stage melanoma patients. Cancer Immunol. Immunother. 2013, 62, 1711-1722. [CrossRef]

47. Weber, J.; Gibney, G.; Kudchadkar, R.; Yu, B.; Cheng, P.; Martinez, A.J.; Kroeger, J.; Richards, A.; McCormick, L.; Moberg, V.; et al. Phase I/II study of metastatic melanoma patients treated with nivolumab who had progressed after ipilimumab. Cancer Immunol. Res. 2016, 4, 345-353. [CrossRef]

48. Fleming, V.; Hu, X.; Weber, R.; Nagibin, V.; Groth, C.; Altevogt, P.; Utikal, J.; Umansky, V. Targeting myeloid-derived suppressor cells to bypass tumor-induced immunosuppression. Front. Immunol. 2018, 9, 398. [CrossRef]

49. Mirza, N.; Fishman, M.; Fricke, I.; Dunn, M.; Neuger, A.M.; Frost, T.J.; Lush, R.M.; Antonia, S.; Gabrilovich, D.I. All-trans-retinoic acid improves differentiation of myeloid cells and immune response in cancer patients. Cancer Res. 2006, 66, 9299-9307. [CrossRef]

50. Iclozan, C.; Antonia, S.; Chiappori, A.; Chen, D.T.; Gabrilovich, D. Therapeutic regulation of myeloid-derived suppressor cells and immune response to cancer vaccine in patients with extensive stage small cell lung cancer. Cancer Immunol. Immunother. 2013, 62, 909-918. [CrossRef]

51. Chen, H.M.; Ma, G.; Gildener-Leapman, N.; Eisenstein, S.; Coakley, B.A.; Ozao, J.; Mandeli, J.; Divino, C.; Schwartz, M.; Sung, M.; et al. Myeloid-derived suppressor cells as an immune parameter in patients with concurrent sunitinib and stereotactic body radiotherapy. Clin. Cancer Res. 2015, 21, 4073-4085. [CrossRef] [PubMed]

52. Ko, J.S.; Zea, A.H.; Rini, B.I.; Ireland, J.L.; Elson, P.; Cohen, P.; Golshayan, A.; Rayman, P.A.; Wood, L.; Garcia, J.; et al. Sunitinib mediates reversal of myeloid-derived suppressor cell accumulation in renal cell carcinoma patients. Clin. Cancer Res. 2009, 15, 2148-2157. [CrossRef] [PubMed]

53. Sevko, A.; Michels, T.; Vrohlings, M.; Umansky, L.; Beckhove, P.; Kato, M.; Shurin, G.V.; Shurin, M.R.; Umansky, V. Antitumor Effect of Paclitaxel Is Mediated by Inhibition of Myeloid-Derived Suppressor Cells and Chronic Inflammation in the Spontaneous Melanoma Model. J. Immunol. 2013, 190, 2464-2471. [CrossRef] [PubMed]

54. Zhang, Y.; Bush, X.; Yan, B.; Chen, J.A. Gemcitabine nanoparticles promote antitumor immunity against melanoma. Biomaterials 2019, 189, 48-59. [CrossRef] [PubMed]

55. Meyer, C.; Sevko, A.; Ramacher, M.; Bazhin, A.V.; Falk, C.S.; Osena, W.; Borrello, I.; Kato, M.; Schadendorf, D.; Baniyash, M.; et al. Chronic inflammation promotes myeloid-derived suppressor cell activation blocking antitumor immunity in transgenic mouse melanoma model. Proc. Natl. Acad. Sci. USA 2011, 108, 17111-17116. [CrossRef]

56. Serafini, P.; Meckel, K.; Kelso, M.; Noonan, K.; Califano, J.; Koch, W.; Dolcetti, L.; Bronte, V.; Borrello, I. Phosphodiesterase- 5 inhibition augments endogenous antitumor immunity by reducing myeloid-derived suppressor cell function. J. Exp. Med. 2006, 203, 2691-2702. [CrossRef] 
57. Hassel, J.C.; Jiang, H.; Bender, C.; Winkler, J.; Sevko, A.; Shevchenko, I.; Halama, N.; Dimitrakopoulou-Strauss, A.; Haefeli, W.E.; Jäger, D.; et al. Tadalafil has biologic activity in human melanoma. Results of a pilot trial with Tadalafil in patients with metastatic Melanoma (TaMe). Oncoimmunology 2017, 6, e1326440. [CrossRef]

58. Sun, L.; Clavijo, P.E.; Robbins, Y.; Patel, P.; Friedman, J.; Greene, S.; Das, R.; Silvin, C.; Van Waes, C.; Horn, L.A.; et al. Inhibiting myeloid-derived suppressor cell trafficking enhances T cell immunotherapy. JCI Insight 2019, 4, 1-12. [CrossRef]

59. Coffelt, S.B.; Wellenstein, M.D.; De Visser, K.E. Neutrophils in cancer: Neutral no more. Nat. Rev. Cancer 2016, 16, 431-446. [CrossRef]

60. Moses, K.; Brandau, S. Human neutrophils: Their role in cancer and relation to myeloid-derived suppressor cells. Semin. Immunol. 2016, 28, 187-196. [CrossRef]

61. Zaragoza, J.; Caille, A.; Beneton, N.; Bens, G.; Christiann, F.; Maillard, H.; Machet, L. High neutrophil to lymphocyte ratio measured before starting ipilimumab treatment is associated with reduced overall survival in patients with melanoma. Br. J. Dermatol. 2016, 174, 146-151. [CrossRef] [PubMed]

62. Xie, X.; Liu, J.; Yang, H.; Chen, H.; Zhou, S.; Lin, H.; Liao, Z.; Ding, Y.; Ling, L.; Wang, X. Prognostic Value of Baseline Neutrophil-to-Lymphocyte Ratio in Outcome of Immune Checkpoint Inhibitors. Cancer Invest. 2019, 37, 265-274. [CrossRef] [PubMed]

63. Kalluri, R. The biology and function of fibroblasts in cancer. Nat. Rev. Cancer 2016, 16, 582-598. [CrossRef] [PubMed]

64. Paraiso, K.H.T.; Smalley, K.S.M. Fibroblast-mediated drug resistance in cancer. Biochem. Pharmacol. 2013, 85, 1033-1041. [CrossRef]

65. Wong, P.F.; Wei, W.; Gupta, S.; Smithy, J.W.; Zelterman, D.; Kluger, H.M.; Rimm, D.L. Multiplex quantitative analysis of cancer-associated fibroblasts and immunotherapy outcome in metastatic melanoma. J. Immunother. Cancer 2019, 7, 194. [CrossRef]

66. Denton, A.E.; Roberts, E.W.; Fearon, D.T. Stromal Cells in the Tumor Microenvironment. Adv. Exp. Med. Biol. 2018, 1060, 99-114.

67. Kraman, M.; Bambrough, P.J.; Arnold, J.N.; Roberts, E.W.; Magiera, L.; Jones, J.O.; Gopinathan, A.; Tuveson, D.A.; Fearon, D.T. Suppression of antitumor immunity by stromal cells expressing fibroblast activation protein-alpha. Science 2010, 330, 827-830. [CrossRef]

68. Zhao, F.; Evans, K.; Xiao, C.; DeVito, N.; Theivanthiran, B.; Holtzhausen, A.; Siska, P.J.; Blobe, G.C.; Hanks, B.A. Stromal Fibroblasts Mediate Anti-PD-1 Resistance via MMP-9 and Dictate TGF $\beta$ Inhibitor Sequencing in Melanoma. Cancer Immunol. Res. 2018, 6, 1459-1471. [CrossRef]

69. Wang, H.; Yang, L.; Wang, D.; Zhang, Q.; Zhang, L. Pro-tumor activities of macrophages in the progression of melanoma. Hum. Vaccin. Immunother. 2017, 13, 1556-1562. [CrossRef]

70. Salmi, S.; Siiskonen, H.; Sironen, R.; Tyynelä-Korhonen, K.; Hirschovits-Gerz, B.; Valkonen, M.; Auvinen, P.; Pasonen-Seppänen, S. The number and localization of $\mathrm{CD}^{+} 8^{+}$and $\mathrm{CD} 163^{+}$macrophages in different stages of cutaneous melanoma. Melanoma Res. 2019, 29, 237-247. [CrossRef]

71. Gartrell-Corrado, R.D.; Chen, A.X.; Rizk, E.M.; Marks, D.K.; Bogardus, M.H.; Hart, T.D.; Silverman, A.M.; Bayan, C.-A.Y.; Finkel, G.G.; Barker, L.W.; et al. Linking transcriptomic and imaging data defines features of a favorable tumor immune microenvironment and identifies a combination biomarker for primary melanoma. Cancer Res. 2020, 80, 1078-1087. [CrossRef] [PubMed]

72. Han, N.; Baghdadi, M.; Ishikawa, K.; Endo, H.; Kobayashi, T.; Wada, H.; Imafuku, K.; Hata, H.; Seino, K. Enhanced IL-34 expression in Nivolumab-resistant metastatic melanoma. Inflamm. Regen. 2018, $38,3$. [CrossRef] [PubMed]

73. Etzerodt, A.; Tsalkitzi, K.; Maniecki, M.; Damsky, W.; Delfini, M.; Baudoin, E.; Moulin, M.; Bosenberg, M.; Graversen, J.H.; Auphan-Anezin, N.; et al. Specific targeting of CD163+ TAMs mobilizes inflammatory monocytes and promotes T cell-mediated tumor regression. J. Exp. Med. 2019, 216, 2394-2411. [CrossRef] [PubMed]

74. Baumgartner, J.; Wilson, C.; Palmer, B.; Richter, D.; Banerjee, A.; McCarter, M. Melanoma Induces Immunosuppression by Up-Regulating FOXP3 ${ }^{+}$Regulatory T Cells. J. Surg. Res. 2007, 141, 72-77. [CrossRef]

75. Ward-Hartstonge, K.A.; Kemp, R.A. Regulatory T-cell heterogeneity and the cancer immune response. Clin. Transl. Immunol. 2017, 6, e154. [CrossRef] 
76. Ha, D.; Tanaka, A.; Kibayashi, T.; Tanemura, A.; Sugiyama, D.; Wing, J.B.; Lim, E.L.; Teng, K.W.W.; Adeegbe, D.; Newell, E.W.; et al. Differential control of human Treg and effector T cells in tumor immunity by Fc-engineered anti-CTLA-4 antibody. Proc. Natl. Acad. Sci. USA 2019, 116, 609-618. [CrossRef]

77. Sharma, A.; Subudhi, S.K.; Blando, J.; Scutti, J.; Vence, L.; Wargo, J.; Allison, J.P.; Ribas, A.; Sharma, P. Anti-CTLA-4 immunotherapy does not deplete Foxp3 p regulatory T cells (Tregs) in human cancers. Clin. Cancer Res. 2019, 25, 1233-1238. [CrossRef]

78. Simpson, T.R.; Li, F.; Montalvo-Ortiz, W.; Sepulveda, M.A.; Bergerhoff, K.; Arce, F.; Roddie, C.; Henry, J.Y.; Yagita, H.; Wolchok, J.D.; et al. Fc-dependent depletion of tumor-infiltrating regulatory $t$ cells co-defines the efficacy of anti-CTLA-4 therapy against melanoma. J. Exp. Med. 2013, 210, 1695-1710. [CrossRef]

79. Bentebibel, S.E.; Hurwitz, M.E.; Bernatchez, C.; Haymaker, C.; Hudgens, C.W.; Kluger, H.M.; Tetzlaff, M.T.; Tagliaferri, M.A.; Zalevsky, J.; Hoch, U.; et al. A first-in-human study and biomarker analysis of NKTR-214, a novel IL2R $\beta \gamma$-biased cytokine, in patients with advanced or metastatic solid tumors. Cancer Discov. 2019, 9, 711-721. [CrossRef]

80. Gopalakrishnan, V.; Spencer, C.N.; Nezi, L.; Reuben, A.; Andrews, M.C.; Karpinets, T.V.; Prieto, P.A.; Vicente, D.; Hoffman, K.; Wei, S.C.; et al. Gut microbiome modulates response to anti-PD-1 immunotherapy in melanoma patients. Science 2018, 359, 97-103. [CrossRef]

81. Matson, V.; Fessler, J.; Bao, R.; Chongsuwat, T.; Zha, Y.; Alegre, M.L.; Luke, J.J.; Gajewski, T.F. The commensal microbiome is associated with anti-PD-1 efficacy in metastatic melanoma patients. Science 2018, 359, $104-108$. [CrossRef]

82. Vetizou, M.; Trinchieri, G. Anti-PD1 in the wonder-gut-land. Cell Res. 2018, 28, 263-264. [CrossRef]

83. Robert, C.; Schachter, J.; Long, G.V.; Arance, A.; Grob, J.J.; Mortier, L.; Daud, A.; Carlino, M.S.; McNeil, C.; Lotem, M.; et al. Pembrolizumab versus ipilimumab in advanced melanoma. N. Engl. J. Med. 2015, 372, 2521-2532. [CrossRef] [PubMed]

84. Buder-Bakhaya, K.; Hassel, J.C. Biomarkers for clinical benefit of immune checkpoint inhibitor treatment-A review from the melanoma perspective and beyond. Front. Immunol. 2018, 9, 1474. [CrossRef] [PubMed]

85. Kambayashi, Y.; Fujimura, T.; Hidaka, T.; Aiba, S. Biomarkers for Predicting Efficacies of Anti-PD1 Antibodies. Front. Med. 2019, 6, 174. [CrossRef] [PubMed]

86. Cho, S.Y.; Lipson, E.J.; Im, H.J.; Rowe, S.P.; Gonzalez, E.M.; Blackford, A.; Chirindel, A.; Pardoll, D.M.; Topalian, S.L.; Wahl, R.L. Prediction of response to immune checkpoint inhibitor therapy using early-time-point 18F-FDG PET/CT imaging in patients with advanced melanoma. J. Nucl. Med. 2017, 58, 1421-1428. [CrossRef]

87. Tan, A.C.; Emmett, L.; Lo, S.; Liu, V.; Kapoor, R.; Carlino, M.S.; Guminski, A.D.; Long, G.V.; Menzies, A.M. FDG-PET response and outcome from anti-PD-1 therapy in metastatic melanoma. Ann. Oncol. 2018, 29, 2115-2120. [CrossRef]

88. Ito, K.; Teng, R.; Schöder, H.; Humm, J.L.; Ni, A.; Michaud, L.; Nakajima, R.; Yamashita, R.; Wolchok, J.D.; Weber, W.A. 18 F-FDG PET/CT for monitoring of ipilimumab therapy in patients with metastatic melanoma. J. Nucl. Med. 2019, 60, 335-341. [CrossRef]

89. Dimitrakopoulou-Strauss, A. Monitoring of patients with metastatic melanoma treated with immune checkpoint inhibitors using PET-CT. Cancer Immunol. Immunother. 2019, 68, 813-822. [CrossRef]

90. Kythreotou, A.; Siddique, A.; Mauri, F.A.; Bower, M.; Pinato, D.J. PD-L1. J. Clin. Pathol. 2018, 71, $189-194$. [CrossRef]

91. Xu-Monette, Z.Y.; Zhang, M.; Li, J.; Young, K.H. PD-1/PD-L1 blockade: Have we found the key to unleash the antitumor immune response? Front. Immunol. 2017, 8, 1597. [CrossRef] [PubMed]

92. Vilain, R.E.; Menzies, A.M.; Wilmott, J.S.; Kakavand, H.; Madore, J.; Guminski, A.; Liniker, E.; Kong, B.Y.; Cooper, A.J.; Howle, J.R.; et al. Dynamic changes in PD-L1 expression and immune infiltrates early during treatment predict response to PD-1 blockade in Melanoma. Clin. Cancer Res. 2017, 23, 5024-5033. [CrossRef] [PubMed]

93. Conroy, J.M.; Pabla, S.; Nesline, M.K.; Glenn, S.T.; Papanicolau-Sengos, A.; Burgher, B.; Andreas, J.; Giamo, V.; Wang, Y.; Lenzo, F.L.; et al. Next generation sequencing of PD-L1 for predicting response to immune checkpoint inhibitors. J. Immunother. Cancer 2019, 7, 18. [CrossRef] [PubMed]

94. Mahoney, K.M.; Shukla, S.A.; Patsoukis, N.; Chaudhri, A.; Browne, E.P.; Arazi, A.; Eisenhaure, T.M.; Pendergraft, W.F.; Hua, P.; Pham, H.C.; et al. A secreted PD-L1 splice variant that covalently dimerizes and mediates immunosuppression. Cancer Immunol. Immunother. 2019, 68, 421-432. [CrossRef] 
95. Zhou, J.; Mahoney, K.M.; Giobbie-Hurder, A.; Zhao, F.; Lee, S.; Liao, X.; Rodig, S.; Li, J.; Wu, X.; Butterfield, L.H.; et al. Soluble PD-L1 as a biomarker in malignant melanoma treated with checkpoint blockade. Cancer Immunol. Res. 2017, 5, 480-492. [CrossRef]

96. Cordonnier, M.; Nardin, C.; Chanteloup, G.; Derangere, V.; Algros, M.P.; Arnould, L.; Garrido, C.; Aubin, F.; Gobbo, J. Tracking the evolution of circulating exosomal-PD-L1 to monitor melanoma patients. J. Extracell. Vesicles 2020, 9, 1710899. [CrossRef]

97. Chen, G.; Huang, A.C.; Zhang, W.; Zhang, G.; Wu, M.; Xu, W.; Yu, Z.; Yang, J.; Wang, B.; Sun, H.; et al. Exosomal PD-L1 contributes to immunosuppression and is associated with anti-PD-1 response. Nature 2018, 560, 382-386. [CrossRef]

98. Del Re, M.; Marconcini, R.; Pasquini, G.; Rofi, E.; Vivaldi, C.; Bloise, F.; Restante, G.; Arrigoni, E.; Caparello, C.; Bianco, M.G.; et al. PD-L1 mRNA expression in plasma-derived exosomes is associated with response to anti-PD-1 antibodies in melanoma and NSCLC. Br. J. Cancer 2018, 118, 820-824. [CrossRef]

99. Sanmamed, M.F.; Perez-Gracia, J.L.; Schalper, K.A.; Fusco, J.P.; Gonzalez, A.; Rodriguez-Ruiz, M.E.; Oñate, C.; Perez, G.; Alfaro, C.; Martín-Algarra, S.; et al. Changes in serum interleukin-8 (IL-8) levels reflect and predict response to anti-PD-1 treatment in melanoma and non-small-cell lung cancer patients. Ann. Oncol. 2017, 28, 1988-1995. [CrossRef]

100. Chow, M.T.; Ozga, A.J.; Servis, R.L.; Frederick, D.T.; Lo, J.A.; Fisher, D.E.; Freeman, G.J.; Boland, G.M.; Luster, A.D. Intratumoral Activity of the CXCR3 Chemokine System Is Required for the Efficacy of Anti-PD-1 Therapy. Immunity 2019, 50, 1498-1512. [CrossRef]

101. Erdag, G.; Schaefer, J.T.; Smolkin, M.E.; Deacon, D.H.; Shea, S.M.; Dengel, L.T.; Patterson, J.W.; Slingluff, C.L. Immunotype and immunohistologic characteristics of tumor-infiltrating immune cells are associated with clinical outcome in metastatic melanoma. Cancer Res. 2012, 72, 1070-1080. [PubMed]

102. Fridman, W.H.; Pagès, F.; Sautès-Fridman, C.; Galon, J. The immune contexture in human tumours: Impact on clinical outcome. Nat. Rev. Cancer 2012, 12, 298-306. [CrossRef] [PubMed]

103. Antohe, M.; Nedelcu, R.I.; Nichita, L.; Popp, C.G.; Cioplea, M.; Brinzea, A.; Hodorogea, A.; Calinescu, A.; Balaban, M.; Ion, D.A.; et al. Tumor infiltrating lymphocytes: The regulator of melanoma evolution (Review). Oncol. Lett. 2019, 17, 4155-4161. [CrossRef]

104. Yamazaki, N.; Kiyohara, Y.; Uhara, H.; Iizuka, H.; Uehara, J.; Otsuka, F.; Fujisawa, Y.; Takenouchi, T.; Isei, T.; Iwatsuki, K.; et al. Cytokine biomarkers to predict antitumor responses to nivolumab suggested in a phase 2 study for advanced melanoma. Cancer Sci. 2017, 108, 1022-1031. [CrossRef] [PubMed]

105. Ayers, M.; Lunceford, J.; Nebozhyn, M.; Murphy, E.; Loboda, A.; Kaufman, D.R.; Albright, A.; Cheng, J.D.; Kang, S.P.; Shankaran, V.; et al. IFN- $\gamma$-related mRNA profile predicts clinical response to PD-1 blockade. J. Clin. Invest. 2017, 127, 2930-2940. [CrossRef]

106. Taube, J.M.; Anders, R.A.; Young, G.D.; Xu, H.; Sharma, R.; McMiller, T.L.; Chen, S.; Klein, A.P.; Pardoll, D.M.; Topalian, S.L.; et al. Colocalization of inflammatory response with B7-H1 expression in human melanocytic lesions supports an adaptive resistance mechanism of immune escape. Sci. Transl. Med. 2012, 4, $127 \mathrm{ra37.}$ [CrossRef]

107. Chicas-Sett, R.; Morales-Orue, I.; Rodriguez-Abreu, D.; Lara-Jimenez, P. Combining radiotherapy and ipilimumab induces clinically relevant radiation-induced abscopal effects in metastatic melanoma patients: A systematic review. Clin. Transl. Radiat. Oncol. 2018, 9, 5-11. [CrossRef]

108. Hiniker, S.M.; Reddy, S.A.; Maecker, H.T.; Subrahmanyam, P.B.; Rosenberg-Hasson, Y.; Swetter, S.M.; Saha, S.; Shura, L.; Knox, S.J. A Prospective Clinical Trial Combining Radiation Therapy With Systemic Immunotherapy in Metastatic Melanoma. Int. J. Radiat. Oncol. Biol. Phys. 2016, 96, 578-588.

109. Rauschenberg, R.; Bruns, J.; Brütting, J.; Daubner, D.; Lohaus, F.; Zimmer, L.; Forschner, A.; Zips, D.; Hassel, J.C.; Berking, C.; et al. Impact of radiation, systemic therapy and treatment sequencing on survival of patients with melanoma brain metastases. Eur. J. Cancer 2019, 110, 11-20. [CrossRef]

110. Jaune, E.; Rocchi, S. Metformin: Focus on melanoma. Front. Endocrinol. 2018, 9, 472. [CrossRef]

111. Scharping, N.E.; Menk, A.V.; Whetstone, R.D.; Zeng, X.; Delgoffe, G.M. Efficacy of PD-1 Blockade Is Potentiated by Metformin-Induced Reduction of Tumor Hypoxia. Cancer Immunol. Res. 2017, 5, 9-16. [CrossRef] [PubMed]

112. Afzal, M.Z.; Mercado, R.R.; Shirai, K. Efficacy of metformin in combination with immune checkpoint inhibitors (anti-PD-1/anti-CTLA-4) in metastatic malignant melanoma. J. Immunother. Cancer 2018, 6, 64. [CrossRef] [PubMed] 
113. Pedersen, L.; Idorn, M.; Olofsson, G.H.; Lauenborg, B.; Nookaew, I.; Hansen, R.H.; Johannesen, H.H.; Becker, J.C.; Pedersen, K.S.; Dethlefsen, C.; et al. Voluntary running suppresses tumor growth through epinephrine- and IL-6-dependent NK cell mobilization and redistribution. Cell Metab. 2016, 23, 554-562. [CrossRef] [PubMed]

114. Dos Santos, C.M.M.; Diniz, V.L.S.; Bachi, A.L.L.; Dos Santos De Oliveira, L.C.; Ghazal, T.; Passos, M.E.P.; De Oliveira, H.H.; Murata, G.; Masi, L.N.; Martins, A.R.; et al. Moderate physical exercise improves lymphocyte function in melanoma-bearing mice on a high-fat diet. Nutr. Metab. 2019, 16, 63. [CrossRef]

115. Schwitzer, E.; Orlow, I.; Zabor, E.C.; Begg, C.B.; Berwick, M.; Thomas, N.E.; Kanetsky, P.A.; Jones, L.W.; Busam, K.J.; Reiner, A.S.; et al. No association between prediagnosis exercise and survival in patients with high-risk primary melanoma: A population-based study. Pigment Cell Melanoma Res. 2017, 30, 424-427. [CrossRef]

116. Hyatt, A.; Drosdowsky, A.; Williams, N.; Paton, E.; Bennett, F.; Andersen, H.; Mathai, J.; Milne, D. Exercise Behaviors and Fatigue in Patients Receiving Immunotherapy for Advanced Melanoma: A Cross-Sectional Survey via Social Media. Integr. Cancer Ther. 2019, 18, 1534735419864431. [CrossRef]

117. Long, G.V.; Stroyakovskiy, D.; Gogas, H.; Levchenko, E.; De Braud, F.; Larkin, J.; Garbe, C.; Jouary, T.; Hauschild, A.; Grob, J.J.; et al. Dabrafenib and Trametinib Versus Dabrafenib and Placebo for Val600 BRAF-mutant Melanoma: A Multicentre, Double-Blind, Phase 3 Randomised Controlled Trial. Lancet 2015, 386, 444-451. [CrossRef]

118. Robert, C.; Karaszewska, B.; Schachter, J.; Rutkowski, P.; Mackiewicz, A.; Stroiakovski, D.; Lichinitser, M.; Dummer, R.; Grange, F.; Mortier, L.; et al. Improved overall survival in melanoma with combined dabrafenib and trametinib. N. Engl. J. Med. 2015, 372, 30-39. [CrossRef]

119. Long, G.V.; Lebbe, C.; Atkinson, V.; Mandalà, M.; Nathan, P.D.; Arance Fernandez, A.M.; Richtig, E.; Yamazaki, N.; Robert, C.; Schadendorf, D.; et al. The anti-PD-1 antibody spartalizumab (S) in combination with dabrafenib $(\mathrm{D})$ and trametinib $(\mathrm{T})$ in previously untreated patients (pts) with advanced BRAF V600-mutant melanoma: Updated efficacy and safety from parts 1 and 2 of COMBI-i. J. Clin. Oncol. 2019, 37, 9531. [CrossRef]

120. Ascierto, P.A.; Ferrucci, P.F.; Fisher, R.; Del Vecchio, M.; Atkinson, V.; Schmidt, H.; Schachter, J.; Queirolo, P.; Long, G.V.; Di Giacomo, A.M.; et al. Dabrafenib, trametinib and pembrolizumab or placebo in BRAF-mutant melanoma. Nat. Med. 2019, 25, 941-946. [CrossRef]

121. Ribas, A.; Lawrence, D.; Atkinson, V.; Agarwal, S.; Miller, W.H.; Carlino, M.S.; Fisher, R.; Long, G.V.; Hodi, F.S.; Tsoi, J.; et al. Combined BRAF and MEK inhibition with PD-1 blockade immunotherapy in BRAF-mutant melanoma. Nat. Med. 2019, 25, 936-940. [CrossRef] [PubMed]

122. Sullivan, R.J.; Hamid, O.; Gonzalez, R.; Infante, J.R.; Patel, M.R.; Hodi, F.S.; Lewis, K.D.; Tawbi, H.A.; Hernandez, G.; Wongchenko, M.J.; et al. Atezolizumab plus cobimetinib and vemurafenib in BRAF-mutated melanoma patients. Nat. Med. 2019, 25, 929-935. [CrossRef] [PubMed]

123. Andtbacka, R.H.I.; Kaufman, H.L.; Collichio, F.; Amatruda, T.; Senzer, N.; Chesney, J.; Delman, K.A.; Spitler, L.E.; Puzanov, I.; Agarwala, S.S.; et al. Talimogene laherparepvec improves durable response rate in patients with advanced melanoma. J. Clin. Oncol. 2015, 33, 2780-2788. [CrossRef] [PubMed]

124. Ribas, A.; Dummer, R.; Puzanov, I.; VanderWalde, A.; Andtbacka, R.H.I.; Michielin, O.; Olszanski, A.J.; Malvehy, J.; Cebon, J.; Fernandez, E.; et al. Oncolytic Virotherapy Promotes Intratumoral T Cell Infiltration and Improves Anti-PD-1 Immunotherapy. Cell 2017, 170, 1109-1119. [CrossRef]

125. Tobin, R.P.; Jordan, K.R.; Robinson, W.A.; Davis, D.; Borges, V.F.; Gonzalez, R.; Lewis, K.D.; McCarter, M.D. Targeting myeloid-derived suppressor cells using all-trans retinoic acid in melanoma patients treated with Ipilimumab. Int. Immunopharmacol. 2018, 63, 282-291. [CrossRef]

126. Hurwitz, M.E.; Cho, D.C.; Balar, A.V.; Curti, B.D.; Siefker-Radtke, A.O.; Sznol, M.; Kluger, H.M.; Bernatchez, C.; Fanton, C.; Iacucci, E.; et al. Baseline tumor-immune signatures associated with response to bempegaldesleukin (NKTR-214) and nivolumab. J. Clin. Oncol. 2019, 37, 2623. [CrossRef]

127. Christmas, B.J.; Rafie, C.I.; Hopkins, A.C.; Scott, B.A.; Ma, H.S.; Cruz, K.A.; Woolman, S.; Armstrong, T.D.; Connolly, R.M.; Azad, N.A.; et al. Entinostat converts immune-resistant breast and pancreatic cancers into checkpoint-responsive tumors by reprogramming tumor-infiltrating MDSCs. Cancer Immunol. Res. 2018, 6, 1561-1577. [CrossRef] 
128. Shen, L.; Ciesielski, M.; Ramakrishnan, S.; Miles, K.M.; Ellis, L.; Sotomayor, P.; Shrikant, P.; Fenstermaker, R.; Pili, R. Class I Histone deacetylase inhibitor entinostat suppresses regulatory $\mathrm{T}$ cells and enhances immunotherapies in renal and prostate cancer models. PLoS ONE 2012, 7, e30815. [CrossRef]

129. Entinostat Helps Thwart Immunotherapy Resistance. Cancer Discov. 2019, 9, 685-686.

130. Gao, S.; Yang, D.; Fang, Y.; Lin, X.; Jin, X.; Wang, Q.; Wang, X.; Ke, L.; Shi, K. Engineering nanoparticles for targeted remodeling of the tumor microenvironment to improve cancer immunotherapy. Theranostics 2019, 9, 126-151. [CrossRef]

131. Zhang, Y.X.; Zhao, Y.Y.; Shen, J.; Sun, X.; Liu, Y.; Liu, H.; Wang, Y.; Wang, J. Nanoenabled Modulation of Acidic Tumor Microenvironment Reverses Anergy of Infiltrating T Cells and Potentiates Anti-PD-1 Therapy. Nano Lett. 2019, 19, 2774-2783. [CrossRef] [PubMed]

132. Ordikhani, F.; Uehara, M.; Kasinath, V.; Dai, L.; Eskandari, S.K.; Bahmani, B.; Yonar, M.; Azzi, J.R.; Haik, Y.; Sage, P.T.; et al. Targeting antigen-presenting cells by anti-PD-1 nanoparticles augments antitumor immunity. JCI Insight 2018, 3, e122700.

133. Terán-Navarro, H.; Calderon-Gonzalez, R.; Salcines-Cuevas, D.; García, I.; Marradi, M.; Freire, J.; Salmon, E.; Portillo-Gonzalez, M.; Frande-Cabanes, E.; García-Castaño, A.; et al. Pre-clinical development of Listeria-based nanovaccines as immunotherapies for solid tumours: Insights from melanoma. Oncoimmunology 2019, 8, e1541534. [CrossRef] [PubMed]

134. Xie, W.; Deng, W.W.; Zan, M.; Rao, L.; Yu, G.T.; Zhu, D.M.; Wu, W.T.; Chen, B.; Ji, L.W.; Chen, L.; et al. Cancer Cell Membrane Camouflaged Nanoparticles to Realize Starvation Therapy Together with Checkpoint Blockades for Enhancing Cancer Therapy. ACS Nano 2019, 13, 2849-2857. [CrossRef]

135. Anderson, A.C.; Joller, N.; Kuchroo, V.K. Lag-3, Tim-3, and TIGIT: Co-inhibitory Receptors with Specialized Functions in Immune Regulation. Immunity 2016, 44, 989-1004. [CrossRef]

136. Lee, W.J.; Lee, Y.J.; Choi, M.E.; Yun, K.A.; Won, C.H.; Lee, M.W.; Choi, J.H.; Chang, S.E. Expression of lymphocyte-activating gene 3 and T-cell immunoreceptor with immunoglobulin and ITIM domains in cutaneous melanoma and their correlation with programmed cell death 1 expression in tumor-infiltrating lymphocytes. J. Am. Acad. Dermatol. 2019, 81, 219-227. [CrossRef]

137. Tundo, G.R.; Sbardella, D.; Lacal, P.M.; Graziani, G.; Marini, S. On the Horizon: Targeting Next-Generation Immune Checkpoints for Cancer Treatment. Chemotherapy 2019, 64, 62-80. [CrossRef]

138. Long, L.; Zhang, X.; Chen, F.; Pan, Q.; Phiphatwatchara, P.; Zeng, Y.; Chen, H. The promising immune checkpoint LAG-3: From tumor microenvironment to cancer immunotherapy. Genes Cancer 2018, 9, 176-189.

139. Kouo, T.; Huang, L.; Pucsek, A.B.; Cao, M.; Solt, S.; Armstrong, T.; Jaffee, E. Galectin-3 shapes antitumor immune responses by suppressing CD8 T Cells via LAG-3 and Inhibiting Expansion of Plasmacytoid Dendritic Cells. Cancer Immunol. Res. 2015, 3, 412-423. [CrossRef]

140. Ascierto, P.A.; Melero, I.; Bhatia, S.; Bono, P.; Sanborn, R.E.; Lipson, E.J.; Callahan, M.K.; Gajewski, T.; Gomez-Roca, C.A.; Hodi, F.S.; et al. Initial efficacy of anti-lymphocyte activation gene-3 (anti-LAG-3; BMS-986016) in combination with nivolumab (nivo) in pts with melanoma (MEL) previously treated with anti-PD-1/PD-L1 therapy. J. Clin. Oncol. 2017, 35, 9520. [CrossRef]

141. Monney, L.; Sabatos, C.A.; Gaglia, J.L.; Ryu, A.; Waldner, H.; Chernova, T.; Manning, S.; Greenfield, E.A.; Coyle, A.J.; Sobel, R.A.; et al. Th1-specific cell surface protein Tim-3 regulates macrophage activation and severity of an autoimmune disease. Nature 2002, 415, 536-541. [CrossRef] [PubMed]

142. Kang, C.W.; Dutta, A.; Chang, L.Y.; Mahalingam, J.; Lin, Y.C.; Chiang, J.M.; Hsu, C.Y.; Huang, C.T.; Su, W.T.; Chu, Y.Y.; et al. Apoptosis of tumor infiltrating effector TIM-3+CD8+ T cells in colon cancer. Sci. Rep. 2015, 5, 15659. [CrossRef] [PubMed]

143. Fourcade, J.; Sun, Z.; Benallaoua, M.; Guillaume, P.; Luescher, I.F.; Sander, C.; Kirkwood, J.M.; Kuchroo, V.; Zarour, H.M. Upregulation of Tim-3 and PD-1 expression is associated with tumor antigen-specific CD8+ T cell dysfunction in melanoma patients. J. Exp. Med. 2010, 207, 2175-2186. [CrossRef] [PubMed]

144. Manieri, N.A.; Chiang, E.Y.; Grogan, J.L. TIGIT: A Key Inhibitor of the Cancer Immunity Cycle. Trends Immunol. 2017, 38, 20-28. [CrossRef] [PubMed]

145. Yu, X.; Harden, K.; Gonzalez, L.C.; Francesco, M.; Chiang, E.; Irving, B.; Tom, I.; Ivelja, S.; Refino, C.J.; Clark, H.; et al. The surface protein TIGIT suppresses T cell activation by promoting the generation of mature immunoregulatory dendritic cells. Nat. Immunol. 2009, 10, 48-57. [CrossRef] [PubMed] 
146. Kurtulus, S.; Sakuishi, K.; Ngiow, S.F.; Joller, N.; Tan, D.J.; Teng, M.W.L.; Smyth, M.J.; Kuchroo, V.K.; Anderson, A.C. TIGIT predominantly regulates the immune response via regulatory T cells. J. Clin. Invest. 2015, 125, 4053-4062. [CrossRef] [PubMed]

147. Solomon, B.L.; Garrido-Laguna, I. TIGIT: A novel immunotherapy target moving from bench to bedside. Cancer Immunol. Immunother. 2018, 67, 1659-1667. [CrossRef]

148. Chauvin, J.M.; Pagliano, O.; Fourcade, J.; Sun, Z.; Wang, H.; Sander, C.; Kirkwood, J.M.; Chen, T.H.T.; Maurer, M.; Korman, A.J.; et al. TIGIT and PD-1 impair tumor antigen-specific CD8+ T cells in melanoma patients. J. Clin. Invest. 2015, 125, 2046-2058. [CrossRef]

(C) 2020 by the authors. Licensee MDPI, Basel, Switzerland. This article is an open access article distributed under the terms and conditions of the Creative Commons Attribution (CC BY) license (http://creativecommons.org/licenses/by/4.0/). 